Review

\title{
Developing a Landscape Design Approach for the Sustainable Land Management of Hill Country Farms in New Zealand
}

\author{
Duy X. Tran *, Diane Pearson ${ }^{\circledR}$, Alan Palmer and David Gray \\ School of Agriculture and Environment, College of Sciences, Massey University, \\ Palmerston North 4414, New Zealand; D.Pearson@massey.ac.nz (D.P.); A.S.Palmer@massey.ac.nz (A.P.); \\ D.I.Gray@massey.ac.nz (D.G.) \\ * Correspondence: D.Tran@massey.ac.nz; Tel.: +64-27-270-4426
}

Received: 11 May 2020; Accepted: 31 May 2020; Published: 3 June 2020

\begin{abstract}
Landscape modification associated with agricultural intensification has brought considerable challenges for the sustainable development of New Zealand hill country farms. Addressing these challenges requires an appropriate approach to support farmers and design a better landscape that can have beneficial environmental outcomes whilst ensuring continued profitability. In this paper we suggest using geodesign and theories drawn from landscape ecology to plan and design multifunctional landscapes that offer improved sustainability for hill country farm systems and landscapes in New Zealand. This approach suggests that better decisions can be made by considering the major landscape services that are, and could be, provided by the landscapes in which these farm systems are situated. These important services should be included in future landscape design of hill country by creating a patterning and configuration of landscape features that actively maintains or restores important landscape functioning. This will help to improve landscape health and promote landscape resilience in the face of climate change. Through illustrating the potential of this type of approach for wider adoption we believe that the proposed conceptual framework offers a valuable reference for sustainable farm system design that can make an important contribution to advancing environmental management globally as well as in New Zealand.
\end{abstract}

Keywords: multifunctional landscapes; landscape services; geodesign; landscape ecology; agricultural landscape planning

\section{Introduction}

The green revolution in agriculture that occurred during the second half of the 20th century has greatly contributed to increased global food and fiber production, which has enabled a rapidly growing world population to be fed [1]. In order to increase productivity, agricultural intensification has taken the form of an increase in single crop cultivation and chemical and mechanical inputs [2]. This has led to negative impacts on the environment, evident through a loss of biodiversity and a decline in soil and water quality [3]. In response to the resultant environmental issues and the need to feed a growing population, agriculture needs to evolve from a production paradigm that has focused primarily on productivity and profitability to a more sustainable paradigm that focuses on how to ensure productivity can support human needs whilst also preserving important land resources and environmental integrity [4]. Recently, society and the market have initiated a shift from a focus on agricultural productivity and intensification to a focus on sustainable farming (with an emphasis towards efficiency, sustainability and resilience) [5]. New Zealand (NZ) is a good example of an agriculturally-focused nation that faces sustainable production challenges. It has achieved great 
improvements in agricultural productivity and product quality over recent decades [6] but progress has come with significant environmental costs [7].

Although New Zealand is accredited as one of the more sustainable countries in the world and was ranked 11th globally in 2019 for sustainable development [8], its agricultural sector is facing a number of significant issues, such as soil degradation [9], water pollution [10], greenhouse gas (GHGs) emissions [11,12] and soil erosion [13]. Moreover, the possible impact of climate change (e.g., increased flood risk, storm damage and drought severity) is also a crucial threat to agricultural production [14]. To respond to these environmental issues farmers are now faced with a situation of having to operate farm systems that are productive and profitable as well as being sustainable with limited impacts on the environment [15]. This is a major challenge facing NZ farmers, as agricultural production could potentially become increasingly constrained by environmental regulations [16] as governments also respond to growing environmental concerns.

The environmental challenges facing future farming systems are likely to strongly impact upon NZ hill country farming. This is because environmental issues compound already high concerns for these farms, which are associated with the contemporary impacts of increasing production costs, market volatility, climate change, highly variable topography and climatic conditions, and more dispersed and isolated families and communities [17]. This means that future hill country farming systems will need to improve its profitability and build resilience in order to be able to adapt to a changing climate whilst reducing its impacts on the environment. To do this, farmers will need good support systems to help with land use decision-making. However, current land use planning and management approaches that support farm and landscape decision-making in NZ reveal several limitations, such as lack of data and model transparency, insufficient collaboration capability among researchers, policy-makers and other end users, and are limited in terms of the communication of modeling results to end-users [18]. Additionally, some land and environmental planning tools are not simple to implement, as farmers are overwhelmed with information and the process required to develop the land and environmental plans [19]. Consequently, these limitations will reduce the effectiveness of land and environmental planning strategies. Therefore, the development of an effective landscape design approach will be central to helping farmers develop profitable and sustainable farming systems in the future.

The multiple objectives of sustainable agriculture require a multifunctional agricultural landscape that promotes agricultural production whilst ensuring environmental standards are met [20], and landscape ecology can have an important role to play in this [21]. Developing a multi-functional agriculture landscape that provides multiple landscape services (i.e., ecosystem services) for society in addition to the service of food and fiber production [22] has become a key focus for sustainable agricultural research and policy-making, and this has been widely discussed internationally [23-26]. However, there is a gap between theory and practice [27], and transferring the concept of creating multifunctional landscapes into the practice of landscape planning and management has proved to be challenging [28]. The reason for this is that agricultural landscape planning needs to be implemented for a specific geographical region that is strongly associated with local knowledge [29]. This needs the planning process to involve the considerations of local people and therefore requires participation and collaboration of the main stakeholders [30]. Often this does not happen and as a result, local people (or "people of the place") may not agree or may not be able to afford the future landscape scenarios proposed by landscape planners [31], so it is critical that the relevant different stakeholder groups can actively contribute to designing the future landscape by bringing their knowledge and aspirations to the table [32]. It is important that effective landscape planning and scenario development involves an iterative collaborative process and that a design-driven perspective is taken [33].

Recently, geodesign has emerged as an efficient instrument for the implementation of sustainable landscape planning [34]. Geodesign integrates geospatial technologies and scientific methods (e.g., geospatial science, environmental science) to inform spatial decision-making based on the knowledge and information obtained from spatial data [35]. By integrating multiple layers of geographic information and spatial analysis models, geodesign enables the identification and development of a 
future landscape that has an appropriate spatial pattern or configuration of landscape features [36]. This also enables the rapid generation of future landscape scenarios for a study area, the ability to visualize change scenarios, and the assessment of the impacts of future landscape designs on multiple landscape functions and services [37]. In addition, visualization tools and iterative quantitative modeling used in geodesign can promote collaboration between participants, as they enable stakeholders to enter into the discussion and express their opinions and aspirations as part of the design procedure [38]. Among the geodesign frameworks that have been published, the operation framework developed by [31] has been disseminated to a wide range of landscape and environmental design situations [39]. This framework considers landscape design as an iterative process in which the collaboration among the group of people involved in the design process (which includes design professionals, the people of the place, information technologists and geographic scientists) is an integral part of the design procedure, and the relevant stakeholders play a central role in all of the design stages [40].

The adaptation of the framework outlined by Steinitz offers a potential solution to guide farm system decision-making for the creation of multifunctional landscapes. This paper develops these ideas by proposing a landscape design approach for the sustainable land use planning and management of hill country farms in NZ. The approach developed utilizes geodesign and the concepts of landscape function and services as informed by landscape ecology. The specific objectives of this paper are to: (i) define the major challenges facing current and future agriculture in the NZ hill country that need to be considered in future farm landscape planning; and (ii) design a framework that can assist in the creation of multifunctional landscapes for sustainable agricultural production. In doing this, the paper highlights the benefits of integrating geodesign into multifunctional landscape planning for the creation of multifunctional farm landscapes in NZ. This research offers a valuable reference for sustainable farm system design that can make an important contribution to advancing environmental management globally as well as in NZ.

\section{Multifunctional Landscape and Geodesign}

\subsection{Multifunctional Landscapes and its Application in Agricultural Landscape Planning}

A multifunctional landscape is seen as being one capable of providing a wide range of landscape services (i.e., ecosystem services) covering three main areas relevant to landscape management, i.e., ecological, cultural and production functions [41]. Natural and semi-natural landscapes are considered as multifunctional landscapes because they provide a variety of goods and services to people, such as food and fiber, climate regulation and water purification [42]. However, multifunctional landscapes of the past have been transformed into more simple landscapes (e.g., single-function landscapes), which have a dominant land use type (e.g., croplands). This is because land managers and decision-makers have focused on increasing agricultural productivity rather than considering the benefits that can be provided by a multifunctional landscape [43]. The transformation of a natural landscape into an agricultural landscape, especially one that is farmed intensively, leads to landscape simplification. This occurs as diverse stands of native vegetation are cleared and replaced with a monoculture, resulting in a loss of biodiversity and a reduction in landscape functions and services [44]. Many studies have demonstrated the negative effects of landscape simplification, such as an increase of insecticide use [45], loss of habitats [46] and a reduction in biological control [47]. As such, developing a multifunctional landscape is increasingly being recognized as offering an appropriate solution for solving the issues and challenges that have arisen from agricultural intensification (i.e., landscape simplification) [20].

A landscape ecological approach based on the concept of the multifunctional landscape has been widely applied in sustainable agricultural landscape planning [48-51]. In the European Union (EU), multifunctional agriculture is significantly encouraged, as it is a key concept of the Common Agricultural Policy for the EU countries [52]. This concept is also applied in many developed countries, 
like the United States of America, Canada and Australia (as cited in [48]). The overall goal of agricultural landscape planning that is based on the concept of the multifunctional landscape is to develop future or alternative landscapes that can enhance and increase the multifunctionality of the current landscape, in order to achieve a better balance between agricultural production and other landscape services [53].

A landscape services approach has been applied in order to examine a wide range of issues in NZ, such as biological control [54], biodiversity [55] and land use planning and management [56-58]. However, some limitations have been identified, such as the obstacles associated with incorporating the landscape services concept into agricultural land use decision-making and the lack of participation and contribution of farmers in the creation of a future multifunctional landscape [59]. Another important limitation is the inadequacy of the link between landscape service supply and demand. For instance, there is a lack of research that assesses the imbalance between landscape service supply and non-market demand in a spatially explicit manner (e.g., where and to what extent in the landscape are certain services generated by agro-ecosystems needed to maintain desirable environmental conditions) [59]. In addition, current research involves limited measurements of landscape services (e.g., biodiversity) other than production services (e.g., food and fiber) across small areas (e.g., farm scale) [60]. Therefore, the ability to fully integrate multiple landscape services into land use planning and the implementation of a collaborative planning process will provide a greater opportunity to address these gaps.

In this research we have used the terms landscape functions and landscape services instead of ecosystem functions and ecosystem services. Although these concepts are often used as synonyms, it is advocated that the use of the terms landscape functions and landscape services is more appropriate, as these terms are more attractive to people outside the ecological sciences and may be more related to local people [61]. In addition, landscape functions and services are more appropriate to landscape planning, which is strongly associated with human involvement, whereas ecosystems are often perceived as merely natural and semi-natural systems [62].

\subsection{Geodesign}

Geodesign is defined as "a design and planning method which tightly couples the creation of design proposals with impact simulations informed by geographic contexts, systems thinking, and digital technology" [37] (p. 29).

Geodesign often involves collaboration among essential groups (e.g., the design experts, geographical information system (GIS) scientists, information technologists and the stakeholders) to develop and decide sustainable scenarios for the future landscape of their area [31]. These groups comprise a geodesign team, and collaborate based on a set of questions and methods, typically within a framework that consists of six key questions [63]:

1. How should the landscape be described in content, space and time?

2. How does the landscape operate?

3. Is the current landscape working well?

4. How might the landscape be altered? By what policies and actions, where and when?

5. What differences might the changes cause?

6. How should the landscape be changed?

Six models are employed to answer each of the six questions, ranging from the description of the study area to the decision on a desired future landscape. The process presented in the framework is an integrated and continuous procedure, because the outcome of each phase serves as an input for the subsequent phase, and all the stages of the design (understand study area, specify methods and perform study) are incorporated into one unified system.

Recently, geodesign has emerged as an innovative design approach, developed to provide alternative scenarios for future landscapes, based on a rich knowledge base about the environment [35]. Geodesign has been extensively applied to different landscape planning and management case studies, such as urban development [64-66], environmental management $[67,68]$, and sustainable agricultural 
land use [69-71]. This approach is also flexible in terms of the scale of application (e.g., a street, a farm, small town, catchment and regional scales) [72,73]. Various examples of geodesign applications were discussed at the Geodesign Summit in 2019 [74]. In the case of agricultural landscape planning, a typical example of the application of geodesign is illustrated through the use of the approach to increase food production and biofuel commodities and improve water quality and habitat performance in the Seven Mile Creek watershed, Minnesota, United States [75]. At the farm scale, another example is a geodesign project that utilizes 3D modeling and geospatial analysis to design strategies for climate change mitigation on a farm in Iowa, United States. This project applies geodesign for real-time scenario development and interactively evaluating alternative farm design [76].

In New Zealand, GIS tools and techniques have been widely applied to solve environmental problems [77-81], but the tools and approaches that link design and GIS have not been readily available [82] and there is a limited number of applications that follow the geodesign framework to solve problems in landscape planning, especially at the farm scale. For instance, only one previous paper was identified that applied geodesign to plan a route for visitor access across a farm in NZ [83]. Meanwhile, there is an absence of geodesign applications that focus on developing a multifunctional agricultural landscape. Hence, research that utilizes geodesign procedures in an agricultural landscape, especially at the farm scale, has the potential to contribute to environmental management studies in NZ but has not yet been fully explored.

\subsection{The Benefits of Integrating Geodesign into Multifunctional Landscape Planning}

Geodesign offers an efficient solution to implement the adaptive design of multifunctional landscape planning. It is an effective approach because it can (1) promote collaborative and adaptive landscape design among different stakeholders, (2) advance landscape multifunctionality in agricultural landscape planning and (3) enable the implementation of the landscape design problem on a large scale. One key advantage of geodesign compared to traditional landscape planning approaches is that it allows for collaboration among researchers, policy-makers, and other end users, because it divides the landscape planning into different processes (with six distinct phases) and allows the participants involved to provide feedback and suggestions at any step in the process [84]. With the latest geospatial technologies (e.g., WebGIS application, human-computer interaction tools), participants can directly interact with both the data and the analysis procedure. This is considered an efficient way to initiate discussion among different stakeholders about alternative futures or visions for the new landscape [85]. In addition, a geodesign framework includes a decision model [63] so this can make the application of landscape planning more adaptive and practical. It supposes that decision-makers may agree with or oppose the proposed change, so the decision model that includes a negotiation process (e.g., discussion) and method (e.g., Delphi method) will be able to effectively build consensus among decision-makers and other stakeholders, as well as able to suggest necessary modifications to the proposed changes or the development of new adapted plans [40]. Additionally, alternative landscape plans are not always going to provide a first and ultimate fix, so decision-makers can iteratively discover the trade-offs and synergies inherent in different design scenarios until a final decision is achieved [27]. In the case of $\mathrm{NZ}$, where agricultural land is under private ownership and farmers are the final decision-makers, the inclusion of a decision model in landscape planning is critical because it increases the role of farmers in the landscape design process. This can potentially facilitate the approval by private landowners of proposed landscape change and therefore make the implementation of future landscape change more feasible [86].

Compared to other landscape design methods and techniques, geodesign has a great potential to break new grounds in the design industry, as it is based on advanced geospatial technologies [87]. State-of-the-art remote sensing, image processing, and GPS tools and techniques enable the collection and processing of large amounts of biophysical data in high spatial and temporal resolution. This means that geodesign can be implemented at various scales [88]. This is an asset in the case of NZ hill country, where geospatial data, and especially data for farm scale application, is poor. For instance, it is 
common that there is a lack of detailed land use land cover (LULC) data at the farm scale, so in this case high-resolution remotely sensed data can be used to produce necessary LULC information. In addition, a wide range of tools, techniques, and models that have arisen from GIS, geospatial information, spatial statistics and computer programming can be incorporated into one spatially informed planning platform so as to allow comprehensive landscape design issues to be resolved (as it is a multidisciplinary or transdisciplinary problem) and to provide a more efficient communication mechanism for the modeling processes and results [89]. Geodesign can also integrate different kinds of environmental and socio-economic models to quantitatively and spatially measure the cost and benefit of implementing alternative land use scenarios [90]. The outcome from each geodesign question, such as landscape structure and pattern, environmental sensitivity and risk, and future landscape scenarios, are presented in a meaningful and intuitive visualization (e.g., dynamic map, table and graph) so as to provide better assistance for decision-makers. Once the farmers can see the environmental issues on their farms and measure how much they must invest and can benefit from the future landscape, they will be more confident to make a decision.

In order to effectively co-design future multifunctional landscapes, non-technical people (i.e., farmers) may require an understanding of the basic landscape concepts, such as different socio-economic and ecological landscape functions and services [34]. Through collaboration with other participants, farmers can receive support from technical people (e.g., scientists) to acquire the necessary knowledge. More importantly, geodesign employs GIS models, tools and applications to incorporate numerous layers of geospatial information and transfer the key multifunctional landscape concepts into realistic visualization forms (e.g., map, graph) [91], as well as to develop future landscape scenarios, visualize them and analyze the impacts of the different proposed landscapes on multiple landscape services [37]. This may encourage farmers to pay attention to not only commerce and food production but also the role of the non-trade functions of agricultural landscapes. In addition, the adaptive design capability of geodesign enables farmers' priorities to be considered, as their preferences or requirements can be set in the land change model and this can subsequently increase the ability to reach a consensus between farmers and other stakeholders on future multifunctional landscape scenarios.

\section{The Case Study}

\subsection{Introduction to New Zealand Hill Country and its Environmnetal Challenges}

New Zealand hill country is defined as land with slopes above $15^{\circ}$ and located below an altitude of $1000 \mathrm{~m}$ above sea level [92]. This landscape type covers a variety of land class types, climatic conditions, geology, and topography properties [93]. The hill country landscape is a mixture of steeplands, rolling land and flat land [94] (Figure 1).

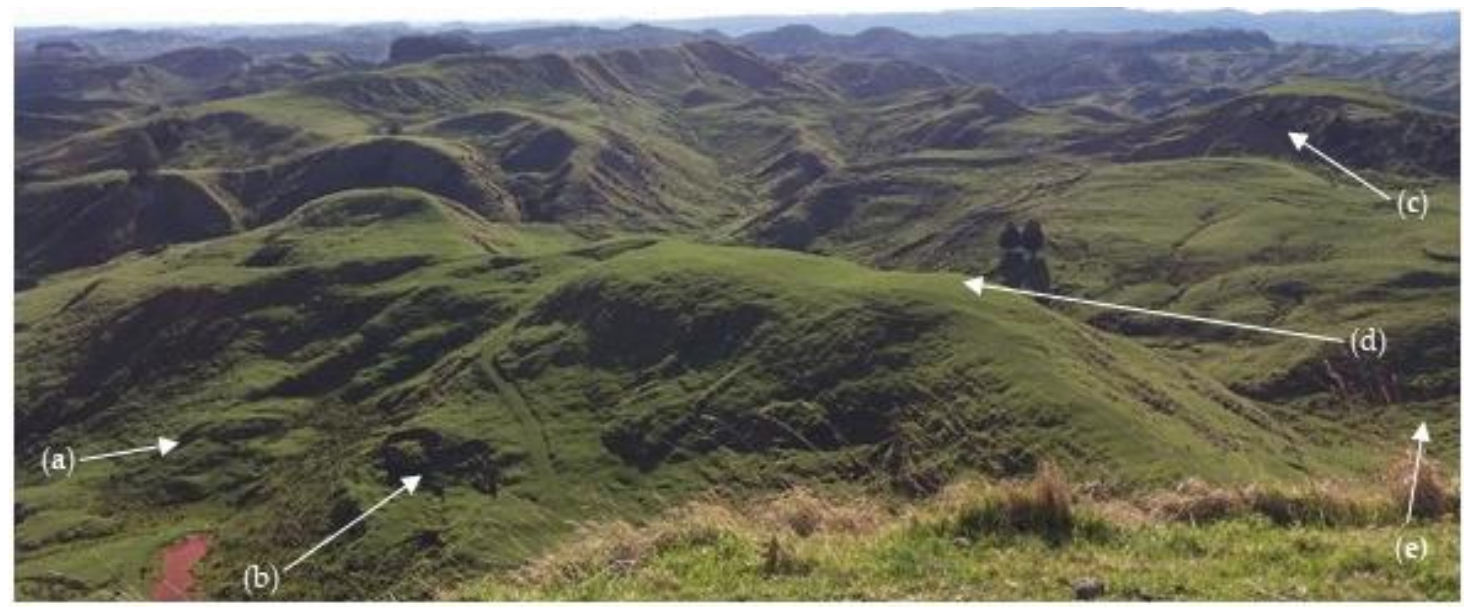

Figure 1. Hill country landscape: (a) earth flow; (b) slump/earth flow; (c) steep slopes $>25^{\circ}$; (d) flat topped ridges; (e) hilly slopes 15-25․ Photographed by Duy X. Tran in 2019. 
Most of the hill country is classified as land use capability classes (LUC $\left.{ }^{1}\right) 5-7$, which are suitable for pastoral grazing, tree crops or production forestry [95]. Other LUC (e.g., classes 3, 4 and 8) often occupy a small proportion of hill country land. Overall, approximately 10 million hectares of NZ's total land area is classified as hill country (approximately $37.5 \%$ of the NZ land surface), with the majority located in the North Island (6.3 million hectares or 23.5\% of NZ's total area) [96]. Approximately half of the hill country land (5 million hectares or 18\% of NZ's total area) is allocated to pastoral farmland used for sheep and cattle farming [97]. It has been reported that sheep and cattle farms, the bulk of which are located on hill country, also own some $25 \%$ of the total native vegetation remaining in NZ [98]. This significant proportion of native vegetation plays an important role in carbon sequestration and biodiversity conservation [99].

In recent years, hill country farms have become increasingly concerned about environmental issues [100]. For instance, Beef and Lamb NZ, an industry organization representing NZ's sheep and beef farmers, has defined four pillars for an environment strategy (created in 2018) for sheep and cattle farms. These include working towards cleaner freshwater, healthy and productive soils, thriving biodiversity and reduced emissions in order to achieve the goal of being carbon neutral by 2050 [98]. However, several environmental problems and the negative effects of climate change are challenging the sustainable development of this type of farming $[17,101]$.

Understanding the major environmental challenges facing hill country farming is vital to ensure that good planning for future landscape and farm systems is made for the future. In the following section, the five major issues that need to be considered prior to landscape planning in order to make progress towards a more sustainable future for hill country farming are examined in the discussion below. These are land use change and deforestation, soil erosion, climate change, agricultural intensification and change in consumers preferences.

Large areas of native forests and shrubland on the steep erodible terrain of NZ hill country were cleared for pastoral farming by the European settlers [102]. Although limited deforestation has occurred since the 1980s, the response to historic deforestation and land clearing is still affecting the current landscape and environment [103]. The negative impact of deforestation has been reflected in a significant increase in soil erosion [104]. Over the last three decades, reforestation and regenerating of native vegetation has been increasingly implemented on hill country [105] to reduce sediment loss from steep slopes into river channels [106] and to increase the capacity for climate change mitigation and adaptation [107]. Plantation forestry has a number of positive effects on the environment, such as a reduction in soil erosion and flooding, an increase in carbon sequestration and a reduction in the GHGs emissions, and it has also reduced pressure on native forests for timber [108]. For instance, a report on erosion-prone hill country (for the period of 1997 to 2002) reported that the area prone to soil erosion had been reduced by 36,000 hectares ( $3 \%$ of the total erosion-prone area) due to the planting of exotic forest or through reversion to native shrublands [104]. However, removal of forest cover at harvest on steeplands can result in significant environmental impacts, such as landslides, debris flows and significant impacts on water quality due to sediment loss into waterways [102].

Over the period of 1990-2015, the total area of hill country sheep and beef farms decreased by approximately 1.3 million ha [100]. This is because the more productive land was converted to dairy farming or higher-value horticultural crops [97] whilst the steeper, less productive land, which is more vulnerable to erosion and generates lower financial returns [109], was converted to an alternative land use, such as forestry, manuka ${ }^{2}$ for honey production or retirement and a return to native vegetation [17]. Recently, carbon farming, which is a conversion from pasture to forest, is emerging as an alternative to sheep and beef farming in hill country due to the dramatic increase in the price of carbon credits, and this conversion can bring high economic profit if this occurs in eligible areas (the land areas where

LUC class 1 is flat highly productive land and LUC class 8 is very steep unproductive land.

Manuka honey is a monofloral honey produced from the nectar of the manuka, a native tree (Leptospermum scoparium) that grows in New Zealand and parts of Australia. 
there has been a net land use conversion to new forests since 1 January 1990) [110]. Therefore, it is important that relevant scientific information (e.g., mapping of suitable areas for alternative land use options) is available so as to allow landowners to make appropriate decisions [111].

In the NZ hill country, soil erosion is a critical issue that contributes to land degradation [112]. The hill country has a high level of both natural and human-induced erosion [113] due to the amalgamation of coarse-textured soils, high slope terrain, high precipitation and agricultural intensification [114]. Soil erosion presents a significant problem to the practices of current pastoral land, and it is especially severe on hill country, which has substantial areas of steep slopes and erodible rocks (e.g., soft rock) [115], especially in combination with high rainfall and high-intensity rainstorms [104]. It is estimated that 192 million tons of soil are lost every year because of erosion and $44 \%$ of this takes place on grassland [116]. Soil erosion does not only represent a reduction in NZ's natural resources, but it also results in a decline in soil productivity and a reduction in water quality [113]. In relation to the economic cost, the effects of soil erosion on hill country can be on-site (e.g., a reduction in productivity) and off-site (e.g., an increase in flood damage in downstream regions) [95]. The cost of erosion control and mitigation has often surpassed the value of the production that can be obtained from that land [117], and an increase in vegetation cover (e.g., regenerating native trees, tree planting and reforestation) has been described as being the most efficient solution for this problem [118]. For instance, it is argued that the reforestation of unstable and degraded land can not only effectively control current erosion problems, but also preclude the formation of new forms of erosion [106]. For these reasons, soil erosion control is important in land use planning and management in hill country. Characterizing the detailed spatiotemporal pattern of soil erosion and the capability of landscape options to reduce this environmental problem are central to managing this issue.

Climate change is recognized as one of the significant challenges facing agricultural development in NZ hill country [109], as the country's land-based economy is profoundly reliant on climatic conditions for the growth of pasture and crops [119]. Increased frequency of intense rainfall events is a threat to soil erosion, predominantly on hill country steepland [113]. The expected increase in drought frequency and intensity in some drier regions may severely affect the water supply, agricultural production and magnitude of wildfire risk [120-123]. Climate change may also directly affect pastoral production, because the seasonal variation of pasture growth is influenced by rising temperatures, $\mathrm{CO}_{2}$ fertilization and changes in rainfall patterns [119]. Thus, climate change may result in greater variation in sheep and cattle growth and productivity [124]. Adaptation solutions have been developed to reduce risks and build resilience to climate change impacts in NZ. Some of the major adaptation strategies put emphasis on a long-term perspective and suggest an integration of climate change adaptation into the decision-making process [125].

The impacts of climate change on hill country farming may also be off-site and long-term [126]. For example, climate-concerned international consumers or markets might result in an increased demand for the outputs from production that has low GHGs emissions [127], which will mean that NZ agricultural production will have to change accordingly to maintain their market share. Considerable effort has been made by both the public and private sector to determine climate change mitigation solutions in NZ, and central to this is to reduce the GHGs emissions caused by agricultural production [128]. For instance, in the agricultural sector it is suggested that changes to land use and pasture management will be key solutions for reducing GHGs emissions along with other strategies (e.g., innovation in animal genetics and breeding) [129]. It is therefore suggested that multiple land use options (e.g., pasture, forestry, horticulture) need to be considered in relevant areas of the hill country and the integration of climate change scenarios needs to be made into future land use plans for more comprehensive land use planning and management models capable of addressing issues related to climate change.

Intensive pastoral farming in hill country increased rapidly from the late 1940s to early 1980s. This was due to the increasing demand and rising prices for meat and wool products on the world market [130]. It was also supported by government subsidies for land development, as well as the 
emergence of new technological developments (e.g., aerial topdressing-application of aircraft for fertilizers spreading and pasture seeding) [131]. Intensive farming during this period was reflected in a re-clearance of a substantial area of native vegetation that was planted in pasture grass for meat and wool production, an extensive application of fertilizers and agrichemicals, and a high stocking rate [132]. Agricultural intensification and inappropriate agricultural practices in the hill country have resulted in negative impacts on the environment. This includes an increase in soil erosion on steeplands where native bush and shrubs were cleared for pasture, a decrease in biodiversity [133], an increase of nutrient leaching [134], a reduction in water quality [135] and a reduction of future carbon stocks [136].

Since 1984, hill country farming has undergone a dramatic reduction in sheep numbers, as more productive pastoral land was converted to other land use types, and farmers also reduced the stocking rate [130]. Recently, sustainable practices such as organic farming have also been increasingly implemented on some NZ hill country farms [137]. These sorts of changes have resulted in both productivity improvement and better environmental outcomes [138,139]. However, despite these successes, some hill country farms have been managed intensively to improve economic profitability and unsuitable agricultural practices are still happening [140,141]. For example, farmers tend to eliminate the reinvading bush, shrubs and exotic weeds in some high-altitude farms, or marginal land is not fenced off, and this limits the restoration of native forest, which can cause problems associated with soil erosion as well as reducing future carbon stocks [136].

With increasing concerns about the environmental impacts of agricultural intensification and the need to mitigate the impacts of climate change, it is necessary to promote a wider uptake of more sustainable agricultural practices in the hill country [131,142]. Several studies have shown that applying appropriate farming practices, such as developing shelterbelts and hedges, using native plants, or riparian plantings can significantly enhance the provision of landscape services (e.g., increase biodiversity, pest control, water purification) [143-146]. Moreover, by applying appropriate land management decisions it is possible to increase farm productivity whist reducing the impacts on the environment [147]. For instance, using soil data, topographic maps and spatial analysis can help to determine optimum fertilizer application to the appropriate areas and assist in the reduction of nitrate runoff [148]. Making informed decisions requires good land use planning and management tools, which can provide detailed land use and environmental information the farm scale.

Meat and fiber from NZ hill country farms are well recognized on the world market because they are safe, nutritious and grass-fed [109]. However, international consumers are increasingly becoming aware of environmental issues that arise from intensive agricultural production and are requesting more eco-friendly agricultural products or products that respect environmental standards [149,150]. Therefore, the way food is produced (i.e., considering factors such as environmental impact, animal welfare and carbon footprint) is becoming an important focus of consumer preference that now needs to be considered alongside the more traditional values associated with high quality [109]. Subsequently, environmental and sustainability standards are being added to the traditional quality and health standard requirements for produce. As a result of changes in consumers' preferences, NZ hill country farmers are required to adopt more sustainable farming systems that take into account the impact of their practices on the environment [151,152]. Adopting more sustainable farming practices will not only improve the environmental health of NZ hill country; it also presents an opportunity for farmers to capitalize on the growing market for environmentally-friendly products. The utilization of effective tools for land use planning and appropriate resource allocation will contribute to solving many of the issues faced by NZ's hill country.

\subsection{Tools and Approaches for Supporting Sustainable Land Use Planning used in New Zealand}

Government organizations, research institutions and the private sector have developed a wide range of land use models and tools to help to address some of the impacts associated with land use issues and environmental concerns in NZ [153] as well as supporting farm and landscape decision-making in hill country [154]. Various types of models have enabled the user to deal with 
specific environmental concerns, such as carbon sequestration [155], greenhouse gas emissions [12], soil erosion [156], nutrient loss [157] or water use [158]. There are also various applications to help farmers deal with the issues of farm production: AgInform [159], BiomeBGC [160], MitAgator [161] and Farmax [162]. There are more complex land use models (e.g., Agent-Based Rural Land Use New Zealand (ARLUNZ) [163], New Zealand Forest and Agriculture Regional Model (NZ-FARM) [164], Waikato Integrated Scenario Explorer (WISE) [101]), which can take into account different factors, such as land use information, socio-economic conditions and environmental parameters (climate, water quality and biodiversity) to provide projected outcomes for land use and environmental, economic and demographic indicators.There are also Whole Farm Plans (WFP), which are a long-established land management tool that is being widely used across NZ to deal with both economic considerations and environmental constraints on farming systems [165]. Recently, the Land and Environment Plan (LEP) was developed by Beef and Lamb NZ to support sheep and beef farmers to have a better understanding about the land and environmental issues that exist on their farms so that they can develop a land use and environment plan to manage these issues [154].

Land use and environmental planning tools and models have contributed significantly to agricultural development as well as supporting farmers in decision-making to address sustainability issues in NZ [18]. However, several improvements are required to increase the effectiveness of the model outcomes. A review conducted by Motu Economic and Public Policy Research in 2018 [18] pointed out some gaps that NZ land use modeling needs to take into account in order to improve its usability. These include increasing the reliability of the data and increasing model transparency, improving collaboration capability among researchers, policy-makers and other end-users, enhancing the communication associated with the model results to stakeholders and enabling a climate change mitigation framework in the land use planning process [18].

Of upmost importance for improving model reliability is the use of data with a better spatial and temporal resolution. It was conceded that NZ lacks good GIS data when compared to many other developed countries [18]. Using data that are too generalized means that it is not possible to achieve accurate analysis, especially at the finer scales (e.g., farm and paddock) [166], as it will fail to capture the variability present at the a farm scale in relation to factors such as variations in slope, soil types, soil fertility and effective rainfall [97]. Therefore, it is important to consider acquiring better data at a high resolution so that land use optimization models can adequately represent the environmental and ecosystem services variability within small farm-scale areas [59]. It is also important to have an appropriate amount of time-series data to enable trends in environmental issues to be examined over time [167]. This is critical for predicting change to the future environment and is an important basis on which to develop long-term land use and environmental planning.

It is also important that land use planning takes into account the collaboration between different stakeholders so that they can be involved in the planning process [18]. Farm system research has evolved to recognize that there needs to be a shift towards more trans-disciplinary approaches to farm system management, which require collaboration and integration of knowledge and ideas between different people, disciplines and methods [168]. A framework that allows the collaboration among researchers, policy-makers and users will enable them to easily and actively be involved in the planning process and develop a comprehensive land use plan that satisfies multiple objectives (i.e., socio-cultural, economic and environment issues).

A land use planning framework needs to enable the integration of different models and tools to better solve different aspects of land use planning. Various tools and applications have been developed to deal with a wide range of the land use and environmental issues in NZ, and these continue to receive support and investment from the government, research institutions and the private sector [169]. However, the integration of different models into a single framework to solve interdisciplinary questions has been limited in NZ [169]. Hence, future land use models need to consider the synergies between different models and techniques so that they can be utilized to solve real world problems. 
It is necessary to improve the communication of both the modeling processes and the outcomes from this process. Some land use and environmental planning tools are not simple to implement, as they require farmers to prepare and enter a large and complicated set of data into the model. Such models may also use several complex spatial analysis processes (e.g., map overlay, multicriteria analysis) to define environmental issues on a farm, which are often difficult to interpret [170]. In fact, land and environmental planning is a spatially complex problem, since it requires the integration of a wide range of geographic information (e.g., soil, land use types, climate variables) to define issues and allocate and plan resource use. Without an appropriate spatial support system, the process is intimidating for farmers, as they are overwhelmed with information [19]. An adaptive spatial-based decision support system incorporating spatial analysis tools and techniques would provide models with the capability to capture, store, manipulate, analyze, manage and visualize land resources and environmental data and information [171]. This would make the results more transparent to the various decision-makers through the use of different forms of visualization (such as interactive maps, graphs and reports).

\subsection{Why Have Multifunctional Landscapes on Hill Country Farms?}

Landscape simplification is significant in the hill country landscapes in NZ, as there has been extensive conversion of the natural vegetation to pastoral land associated with the expansion of agriculture since European settlement [172] (Figure 2). The area under pasture has increased rapidly from less than 70,000 hectares in 1861 to 1.4 million hectares in 1881, 4.5 million hectares in 1901, and 7.7 million hectares in 2016 [173,174]. The conversion of natural ecosystems (e.g., forest, shrubs) to pasture has led to a degradation of landscape functions in the sense that provisioning services (e.g., grazing production) are dominant and increasing, whereas regulating services are weak and declining. In other words, the human need to produce food has eroded the capacity of the ecosystems to produce other essential services (e.g., regulating services) [175]. The negative impacts of landscape intensification on hill country are well documented, such as the impacts on the provision of freshwater [176], soil and plant biodiversity $[177,178]$ or soil biogeochemical cycling of nutrients [179].
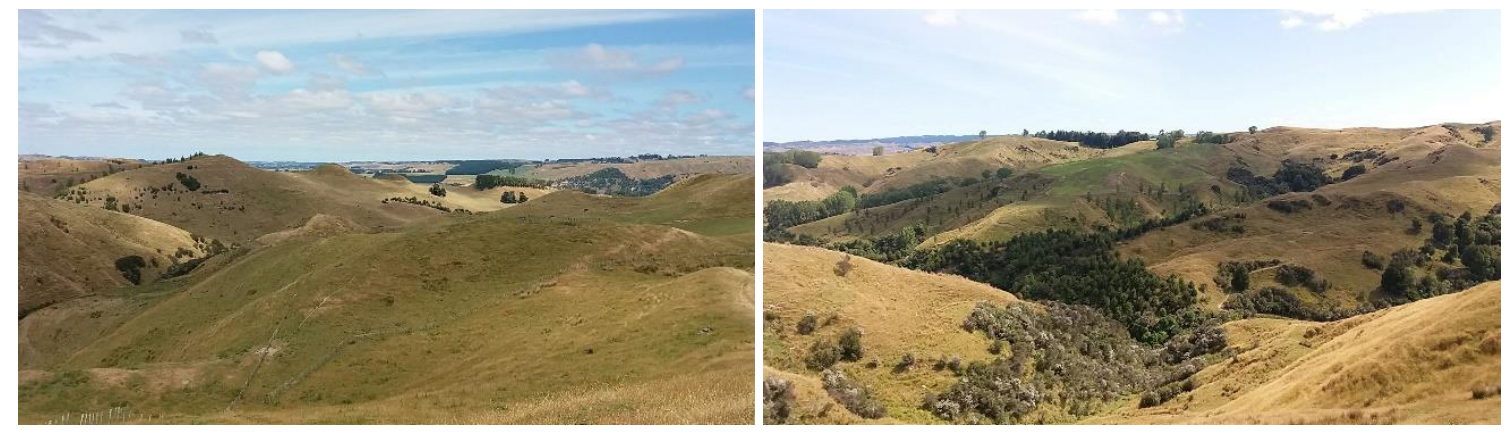

Figure 2. Example of NZ hill country landscapes: high simplification with low regulating services (left); low simplification with high regulating services (right). Photographed by Duy X. Tran in 2019.

It is suggested that the issues that originate from landscape simplification due to agricultural intensification could only be solved by taking into account the redesign of agricultural landscapes [180]. The goal of the approach suggested in this paper is to redesign (or plan) the agricultural landscape to achieve a better balance between ecological, cultural and production functions [180]. The cultural and production functions reflect the capability of the landscape to produce goods and services that support human demand from a socio-economic perspective [181]. Whereas maintaining and improving the ecological functions of the landscape is thought to increase biodiversity and landscape connectivity, which has important conservation and landscape resilience implications, including the ability to adapt to climate change and disturbance [182-185]. The creation of this kind of landscape is expected to be an effective solution to solve the problems related to landscape simplification in NZ hill country farms. 
The justification for this is that a multifunctional agricultural landscape that is made up of a mosaic of natural habitat areas and agricultural production areas could help to maximize the balance of ecological and socio-economic demands and minimize the conflicts between them [186]. This allows the landscape to provide multiple services and achieve multiple objectives (both agricultural production demand and environmental standards) [51,187]. By diversifying farming activities, farmers can secure various income sources whilst at the same time promoting the cultural and natural heritage [188]. For instance, a sustainable multifunctional agricultural landscape may provide the option to develop agritourism or environmental education. Consequently, this contributes to an added income for farmers and increases public interest in the social and environmental values that the farms bring to the community. However, the challenge comes in determining how to implement the multifunctional landscape approach as a practical application to develop a sustainable agricultural landscape where different land use and land cover types (e.g., wetland pasture, forest, and horticulture) co-exist and the land use pattern is appropriate to maintain and promote sufficient heterogeneity so that different landscape functions work properly $[189,190]$.

\section{A Conceptual Framework that Combines Multifunctional Landscapes and Geodesign Concepts for Sustainable Agricultural Landscape Planning}

In this paper, we propose a conceptual framework for sustainable agricultural landscape planning (Figure 3) that integrates the concept of multifunctional landscapes with a geodesign approach. It also draws on several studies that have focused on developing a framework for landscape planning $[87,187,191]$. The geodesign processes in this framework follows the approach outlined by Steinitz [31], which comprises six phases. These phases are: (1) Landscape description, (2) Landscape process; (3) Landscape evaluation; (4) Future landscape scenarios development; (5) Impact assessment of alternative landscape scenarios; and (6) Decision-making. Within this framework, the basic concepts of a multifunctional landscape and a landscape services approach can be fully integrated.

\subsection{Landscape Description}

The landscape description phase is used to describe a general picture of the study area. The first task is to define an appropriate boundary for the study area. It is suggested to consider both the social and ecological boundaries (i.e., boundaries that cover both the ecological and socio-political/cultural functions of the landscape) when defining the boundary for the study area [192,193]. The ecological boundary of the study area may be determined based on ecological processes or biophysical constraints (e.g., land management unit, catchment or sub-catchment boundaries) [194]. The cultural functions of the landscape sometimes may not align with the boundary of the ecological functions, so it is recommended to work with the "people of the place" to properly define an appropriate boundary [192]. In NZ, a catchment group is a community network of farmers who operate in a particular catchment. They are increasingly committed to tackling environmental issues and responding to a long-term sustainable development plan for the catchment $[195,196]$. Working with such groups offers the potential to assist in developing a relevant cultural boundary.

Once the study area boundary is defined, the next step is collecting necessary physical and socio-economic data, especially data for characterizing landscape services and environmental issues (e.g., soils, topography, LULC, climate). In the case of NZ hill country, the lack of data is a limiting factor for analysis. To navigate around this requires an integration of multiple data sources that may come from the government, research institutions, remote sensing and field surveys. In fine-scale applications, such as those undertaken at the farm and paddock scales, information provided by farmers (e.g., stocking unit, grazing rotation) is an important source of data. The integration of local and global data to model landscape services is therefore a valuable option to address data deficiencies in remote and data-poor areas [197]. In addition, data are normally archived in different formats, standards and scales, so data standardization is an important step to make sure multiple data layers can be appropriately integrated and used. 


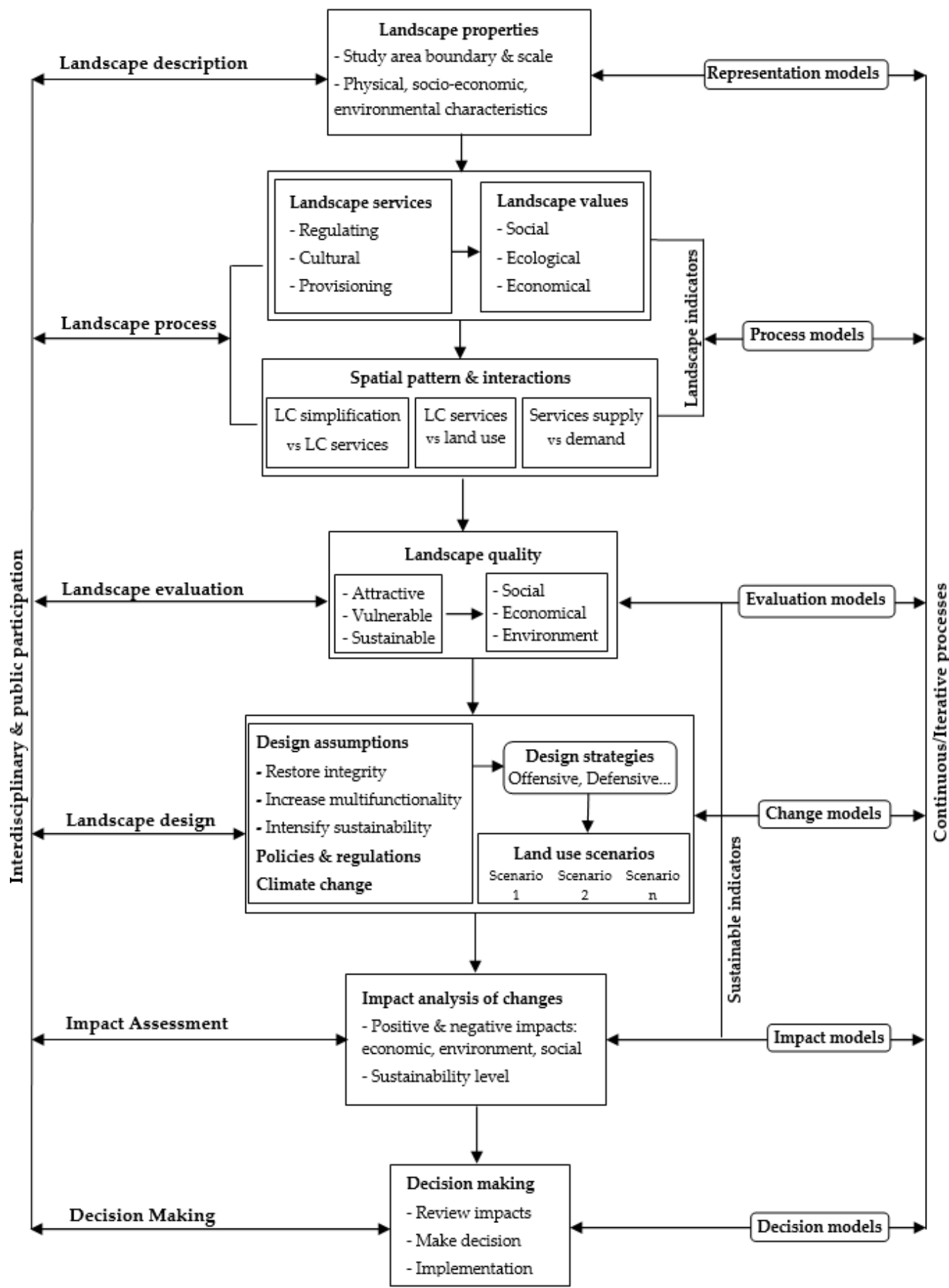

Figure 3. A conceptual framework for a multifunctional landscape-based geodesign for sustainable landscape planning, adapted from Steinitz [31].

A representation model (e.g., a raster-based 2D data model) is used to organize and visualize data collected for the study area through space and over time. For example, maps visualize LULC types of a farm or rainfall and temperature patterns in a catchment from 20-30 years ago to the present. This gives a general understanding of the landscape (from the past to the present) and provides necessary input for the other stages of the framework. Data resolution and availability will affect all other processes of landscape design, as the difference in the resolution and level of data accuracy in the input process could lead to completely different results. For instance, small landscape features (e.g., small plots of shrubs or ponds) play an important role in a farm, such as providing biodiversity, water resources and 
shade for stocks. However, these features are often eliminated in the low-resolution data (e.g., LULC at the catchment or smaller scale), so landscape services provided by these features may not be quantified when using such coarser data.

\subsection{Landscape Process/Operation}

The landscape process phase aims to define key processes in the study area that include both physical/ecological drivers and socio-economic drivers. The first step is spatially and quantitatively characterizing major landscape functions, services, and values. This provides insights into the landscape operation in which important landscape characteristics are examined. An example of major landscape functions or services supply and their indicators on a hill country landscape in NZ is presented in Table 1. It is important that landscape service supply is estimated in monetary units so that the overall benefit that a landscape provided can be easily measured. Various economic valuation methods have been used for estimating the value of landscape services, such as market prices, replacement cost and provision cost [57]. For instance, the market price method can be applied directly to convert several landscape services (e.g., pasture and timber production, carbon sequestration) to appropriate monetary units. Many indirect use services (e.g., drought mitigation, flood mitigation, nutrient retention) may require using provision cost or replacement cost methods to transfer their qualities to monetary value. Additionally, the economic value of landscape aesthetics in an area can be evaluated by estimating people's willingness to pay for visiting heritage or tourist sites distributed in the landscape.

Table 1. Example of landscape services in the hill country New Zealand.

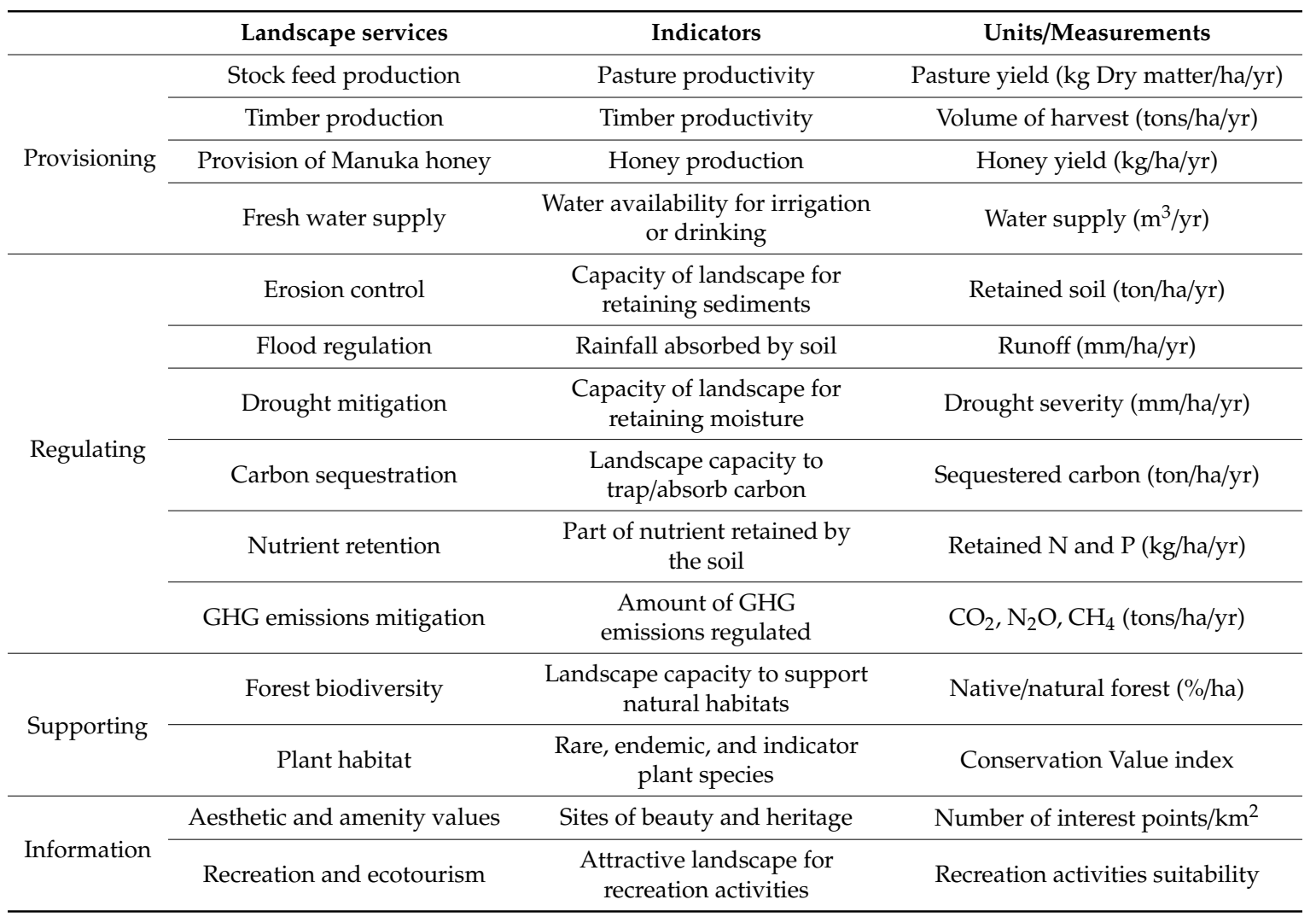

Sources: adapted and revised from [57-60,206,207].

After that, the spatial interaction between the provision of landscape services and landscape simplification and LULC dynamics are analyzed to determine how these processes are linked to each other. A substantial number of studies have stated that the provision of landscape services has been significantly affected by LULC dynamics [198-203]. Quantifying these relationships will be a key to transferring a multifunctional landscape design to a future land use plan. Landscape indicators 
that reflect the landscape simplification (i.e., agricultural intensification) well (e.g., the proportion of cropland and semi-natural land obtained from LULC data [45]), the variations in landscape services provision (e.g., landscape services change index [204] or multifunctionality index [205]) and spatial regression analysis will be used to characterize the spatial interactions between the change in LULC and variations in landscape services.

Quantifying and mapping landscape services can help farmers recognize and understand the multiple values of their farms. This is an advantage compared to using land cover information, as many landscape services may not be directly quantified by using land cover data alone [208]. Understanding major landscape processes and the interaction between them is the key basis for designing a sustainable multifunctional landscape.

\subsection{Landscape Evaluation}

The landscape evaluation phase seeks to assess whether the landscape is working well or not [28], in other words, assessing the overall quality of the landscape [209]. In a multifunctional landscape this can be understood as assessing the quality of goods and services that a landscape provides to humans and the environment. To determine landscape quality, an evaluation model that utilizes comprehensive indicators will be used to evaluate the attractiveness, vulnerability and sustainability of the study area. Attractiveness refers to the advantages that landscapes may have for a specific land use purpose or for socio-economic activities (e.g., suitable soil and climate conditions for fruit production). The vulnerability relates to characteristics that negatively contribute to socio-economic development or the environment (e.g., impacts of extreme climate and steep slopes on agricultural production, or negative effects of agricultural intensification on water quality and biodiversity). Sustainability reflects the landscape's capacity for steadily supplying long-term landscape services that are critical for maintaining human and environmental well-being (e.g., a landscape that has different functions and services that co-exist and balance) [210].

Landscape assessment indicators, which can be of various types, including single (e.g., GHG emissions mitigation index), multiple (e.g., a combined-index integrating several parameters, such as soil erosion control, carbon sequestration and drought mitigation), static (the sustainable threshold being classified into a fixed category) and dynamic (the sustainable threshold being subjected to the dynamic interaction between indicators) $[87,211]$, and come from various sources (e.g., expert consultant, environmentalist, empirical analysis, law and regulation) [31], could be used to assess past and present situations of a study site, monitor the design process and compare design alternatives [87]. Hence, choosing appropriate indicators is important for the success of a landscape design project. Suitable landscape indicators should satisfy several requirements, such as the capability to reflect a wide range of landscape services to analyze the trade-offs between landscape service provision and land use change options [212], providing reliable, detailed, understandable, comparable and spatially explicit information to support decision-making [213], and providing cost-effective indicators by utilizing available data or employing low-cost generated data and models [214].

Landscape evaluation models also need to reside within the geographical context in the sense that assessment indicators should recognize and align with existing legitimized environmental strategy and policy and reflect major landscape processes in the study area. For example, in the case study of hill country in NZ, water quality, soil erosion control, drought mitigation, pasture productivity and GHGs emission mitigation could be used as some of the indicators for landscape sustainability assessment.

\subsection{Future Landscape Scenarios Development}

Based on the results achieved from the landscape evaluation process, change models will be used to define a series of alternative future scenarios for the proposed multifunctional landscapes. In this stage, stakeholders can follow the scenarios developed by scientists or propose their scenarios (a user-defined plan) for the future landscape. Alternative scenarios for future landscape design can be implemented by applying the following procedure: 
First, the information on landscape process (characters, services and values) as well as major socio-economic drivers and environment issues are used to define how the landscape should be changed. Determining the expected future landscape is based on several assumptions, such as the preferences of local people, the landscape functions or services that the future landscape will be capable of providing, and the implications of policies and regulations [215]. In agricultural landscapes, the design goal for future landscapes is mainly based on the level of agricultural intensification (or landscape simplification) [216]. Landscapes that have been highly simplified may need to be redesigned in order to restore integrity between provisioning, supporting, regulating and cultural services, whereas the likely design goal for less simplified landscapes is to increase provisioning services while maintaining current levels of other services [180]. Climate change scenarios can be integrated in this step to measure how the changes in climate variability can affect the landscape operation through the interaction with landscape functions.

Afterwards, a design strategy that could take an offensive approach (where the design goal is utilizing the advantageous or attractive landscape characteristics to develop a future landscape), or a defensive approach (where the development of a future landscape is based on one that avoids vulnerability or risks), or a combination of these approaches, will be used to create a specific change model to simulate future change for the landscape [31]. There are different methods of designing for landscape change, such as rule-based, optimized, and agent-based approaches (see [31] (pp. 56-59) for further details). Among these, the use of multi-criteria decision-making (MCA) can be an efficient method to propose future landscape scenarios in the study area, as the creation of a future landscape can be regarded as a complex MCA process [217]. Each land use scenario or option often requires multiple objectives (e.g., erosion control, carbon sequestration, pasture productivity, GHGs emission) and the final decision will be a compromise between the interests of the different stakeholders involved in the design process. The results from these approaches are maps showing the future landscape with the distribution and pattern of different LULC types. Associated with each LULC map will be the provision of landscape services and landscape multifunctionality maps. For each scenario and stage, different alternatives can be created and reassessed iteratively until consensus is achieved.

\subsection{Impact Assessment}

In the impact assessment of alternative landscape options, the criteria and indicators used in landscape evaluation will be applied to assess the positive and negative impacts (benefits, risks and sustainability) of the future landscape. In a geodesign project, an environmental impact assessment is often implemented to characterize the consequences of the proposed change. In the context of developing a multifunctional agricultural landscape, the impact assessment is related to quantifying the costs and benefits (including both socio-economic and environmental costs) of recovering landscape functions or re-designing the landscape to increase landscape diversification (or landscape multifunctionality). The results of this stage include maps and statistical data showing the cost-benefit ratio of each alternative landscape option. For instance, associated with each land use scenario will be maps showing landscape services provision and value of carbon sequestration, GHGs emissions, erosion control, drought mitigation and pasture productivity, as well as the total benefit (value) of that scenario. This includes the cost to implement such a landscape (e.g., loss of pastoral area, fencing cost, tree planting cost). This will be critical for the decision-making stage.

\subsection{Decision-Making}

In the last phase, the scenario analysis and group discussion will be conducted with the public, experts and stakeholders. The results of the future landscape scenario development and impact analysis will be utilized for discussion, and this will from a basis for making the final decision. According to Steinitz [31], participants in the geodesign process might give different answers, including "Yes", "Maybe" and "No", in response to proposed scenarios. If decision-makers agree with one of the proposed plans, the next stage is to develop the implementation plan. In case stakeholders are not sure 
about their decision, further study or analysis is needed to provide more information to help them decide. Sometimes decision-makers may not approve the designed landscape. If this is the case it is necessary to get comments and feedback on why this is so. This will be valuable information to integrate into the landscape project in the future.

The proposed framework in this research inherits the major advantages exhibited by a geodesign approach. These include the fact that it can be a continuous procedure, a multidisciplinary or transdisciplinary approach, and a participatory collaborative planning technique. Moreover, this framework integrates concepts drawn from landscape ecological theory (such as incorporating information on landscape functions and services, landscape simplification and landscape pattern). This means that the theory provides the scientific context to informed and collaborative decision support processes for farm systems that are faced with the need to change in response to environmental pressures and market influences.

\section{Conclusions}

This paper reviewed the major challenges facing NZ hill country farms and proposed an approach for sustainable agricultural landscape planning. The significant issues facing hill country farming include land use changes and deforestation, soil erosion, agricultural intensification, climate change and the impacts of changes in consumers' preferences. These challenges are considerations for farmers striving towards the long-term sustainable development of NZ's hill country. Currently, landscape simplification associated with agricultural intensification is a significant feature of hill country farms. This may reduce the landscape's capacity to mitigate and adapt to the environmental challenges and climate change effects. Therefore, we have suggested that designing a more sustainable multifunctional landscape is a possible solution to tackle the issues facing NZ hill country. The development of multifunctional agricultural landscapes can contribute towards innovative future farming systems that can deal with emerging environmental issues [218]. In addition, the design of multifunctional landscapes can improve their resilience to change and disturbance [219], which will be crucial for ongoing sustainability in NZ hill country.

This is one of the first studies to propose a geodesign framework for sustainable multifunctional agricultural landscape planning in NZ. By integrating a multifunctional landscape approach in a geodesign context we offer a solution to address some of the implementation problems that have restricted uptake. Considering landscape planning in a design-driven perspective, geodesign embraces collaborative planning (among different stakeholders) as the key to landscape design. It also enables the incorporation of stakeholder values and aspirations as a central element to this process. By dividing the landscape design process into different phases and utilizing geospatial technologies (e.g., human-computer interaction), geodesign allows important stakeholders to be effectively involved and contribute to the planning process. In addition, geodesign enables the use of multiple sources of relevant spatial and temporal resolution data for landscape planning, especially in large-scale applications, as well as being better at dealing with different aspects of land use planning.

The proposed framework in this paper considers the major concepts associated with a multifunctional landscape approach, including landscape functions and services, landscape supply and demand, the value of landscape services, sustainable landscape indicators, spatial patterns and interactions. This facilitates a comprehensive implementation of the multifunctional landscape approach in land use planning and management. A landscape ecological approach has been talked about conceptually for landscape sustainability but has not been widely applied practically in NZ. Therefore, the comprehensive integration of a landscape services approach in landscape planning offers a solution to address some of the limitations faced by current land use planning and management practices in NZ $[59,60]$. The proposed approach and associated framework can provide a scientific basis towards the development of a future commercial land and environmental planning tool. This will hopefully give farmers and rural professionals more options to conduct useful land use planning at the farm scale. 
We believe that the proposed conceptual framework of an integrated landscape ecological (the scientific theory behind a multifunctional landscape concept) and geodesign approach will be a valuable reference for future work about agricultural landscape planning. Ideas around creating multifunctional farm landscapes have been discussed $[24,220,221]$, the role that geodesign can play in future planning has been explored $[34,210]$ and frameworks for developing sustainable landscape based on an integration of geodesign and landscape ecology have been proposed [87,222]. However, there is a lack of a detailed framework that can demonstrate how concepts associated with the generation of multifunctional landscapes can be incorporated into a geodesign process to create a planning tool at the farm scale. Hence, the approach proposed in our paper, which covers a comprehensive description of a type of geodesign process applied to the management of a multifunctional agricultural landscape, will significantly contribute to environmental management studies and illustrate the potential of this type of approach for global application.

Although the framework proposed in this paper demonstrates a comprehensive approach for agricultural landscape planning that can be applied to NZ hill country farms, we acknowledge that future work needs to consider and investigate the issue regarding the financial resources required to support the farmers to overcome their economic concerns associated with changes in land use. Farmers may recognize and be motivated by the great value that extra landscape services can provide and agree with a proposed landscape design, but a barrier to implementation of this design might be the lack of the long-term support that is needed to enable them to be able to afford the cost of implementation and to follow the suggested revised land use and environmental plan. For instance, increasing native woody vegetation on a farm provides a great range of landscape services, but it may potentially affect economic profit in the short term due to the fact that it would decrease land available for grazing and has a low growth rate [223], and thus have less earning capacity in its early life stages. A solution to this is for policy-makers in NZ to consider payment for landscape services. In many countries a wide range of regulating and supporting services are estimated in terms of economic value, and the farmers (i.e., landowners) are able to get a payment for these services [224-226]. Currently, farmers in $\mathrm{NZ}$ can only receive payment for carbon sequestration services, so there are no strong incentives to encourage farmers to implement a land use plan that promotes multiple landscape services on their farm. An approach such as the one outlined in this paper can help to demonstrate a proof of concept to policy-makers so that they recognize the greater environmental value that farmers can provide by designing future landscapes for multifunctionality and landscape services and therefore build financial support into future policy-making.

Author Contributions: All authors contributed to the research. D.X.T. conceptualized the main idea of the study. D.X.T. and D.P. designed the structure of the paper. D.X.T., D.P., A.P. and D.G. contributed to the writing of the manuscript. D.P., A.P. and D.G. supervised the final paper content and edited the writing. All authors have read and agreed to the published version of the manuscript.

Funding: This research received no external funding.

Acknowledgments: Acknowledgement is given to Massey University for supporting this research. The authors would like to acknowledge the valuable comments of three anonymous reviewers that assisted with the finalization of this manuscript.

Conflicts of Interest: The authors declare no conflict of interest.

\section{References}

1. Welch, R.M.; Graham, R.D. A new paradigm for world agriculture: Meeting human needs: Productive, sustainable, nutritious. Field Crop. Res. 1999, 60, 1-10. [CrossRef]

2. Kenmore, P.E.; Stannard, C.; Thompson, P.B. The Ethics of Sustainable Agricultural Intensification; FAO: Rome, Italy, 2004; Volume 4.

3. Kanianska, R. Agriculture and Its Impact on Land-Use, Environment, and Ecosystem Services; IntechOpen: London, UK, 2016; pp. 1-26. 
4. Food and Agriculture Organization of the United Nations (FAO). Transforming Food and Agriculture to Achieve the SDGs: 20 Interconnected Actions to Guide Decision-Makers; FAO: Rome, Italy, 2018.

5. Proudfoot, I. KPMG Agribusiness Agenda: The Big Opportunities and Challenges Facing New Zealand Agriculture: Reflections of the Views of Industry Leaders; KPMG: Auckland, New Zealand, 2010.

6. Robertson, M. Agricultural Productivity in Australia and New Zealand: Trends, Constraints and Opportunities. Available online: https://www.grassland.org.nz/publications/nzgrassland_publication_11.pdf (accessed on 20 May 2020).

7. Baskaran, R.; Cullen, R.; Colombo, S. Estimating values of environmental impacts of dairy farming in New Zealand. N. Z. J. Agric. Res. 2009, 52, 377-389. [CrossRef]

8. Sachs, J.; Schmidt-Traub, G.; Kroll, C.; Lafortune, G.; Fuller, G. Sustainable Development Report 2019. Available online: https://s3.amazonaws.com/sustainabledevelopment.report/2019/2019_sustainable_ development_report.pdf (accessed on 25 July 2019).

9. Ministry for the Environment and Stats NZ. Land Report Highlights Issues with Soil Degradation; Ministry for the Environment and Stats NZ: Wellington, New Zealand, 2018.

10. Duncan, R. The challenges of regulating diffuse agricultural pollution to improve water quality A science policy perspective on approaches to setting enforceable catchment load limits in New Zealand. Case Stud. Environ. 2017, 1. [CrossRef]

11. Kelliher, F.M.; Cox, N.; Van der Weerden, T.J.; De Klein, C.A.M.; Luo, J.; Cameron, K.C.; Di, H.J.; Giltrap, D.; Rys, G. Statistical analysis of nitrous oxide emission factors from pastoral agriculture field trials conducted in New Zealand. Environ. Pollut. 2014, 186, 63-66. [CrossRef] [PubMed]

12. Safa, M.; Nuthall, P.; Nejat, M.; Greig, B. Predicting $\mathrm{CO}_{2}$ Emissions from Farm Inputs in Wheat Production using Artificial Neural Networks and Linear Regression Models "Case study in Canterbury, New Zealand". Int. J. Adv. Comput. Sci. 2016, 7, 268-274.

13. Fernandez, M.A. Adoption of erosion management practices in New Zealand. Land Use Policy 2017, 63, 236-245. [CrossRef]

14. Reisinger, A.; Mullan, B.; Manning, M.; Wratt, D. Global and Local Climate Change Scenarios to Support Adaptation in New Zealand: Future Scenarios and Some Sectoral Perspectives; New Zealand Climate Change Centre: Wellington, New Zealand, 2010; pp. 26-43.

15. Dewes, A.M. Economic Resilience and Environmental Performance of Dairy Farms in the Upper Waikato Region. Master's Thesis, University of Waikato, Hamilton, New Zealand, 2014.

16. Ministry for the Environment. National Policy Statement for Freshwater Management; Ministry for the Environment: Wellington, New Zealand, 2019.

17. Scrimgeour, F. Pathways ahead for New Zealand hill country farming. J. N. Z. Grassl 2016, 78, 73-82.

18. Hendy, J.; Timar, L.; White, D. Land-Use Modelling in New Zealand: Current Practice and Future Needs; Motu Economic and Public Policy Research: Wellington, New Zealand, 2018.

19. Synge, K. An evaluation of the Land and Environment Planning Toolkit for Advancing Soil and Nutrient Management in Hill Country and Steepland Farm Systems. Master's Thesis, Massey University, Palmerston North, New Zealand, 2013.

20. McGranahan, D. Ecologies of scale: Multifunctionality connects conservation and agriculture across fields, farms, and landscapes. Land 2014, 3, 739-769. [CrossRef]

21. Pearson, D. Key Roles for Landscape Ecology in Transformative Agriculture Using Aotearoa-New Zealand as a Case Example. Land 2020, 9, 146. [CrossRef]

22. Lankoski, J. Multifunctional Character of Agriculture; Maatalouden taloudellinen tutkimuslaitos; Agricultural Economics Research Institute: Helsinki, Finland, 2000.

23. Estrada-Carmona, N.; Hart, A.K.; DeClerck, F.A.J.; Harvey, C.A.; Milder, J.C. Integrated landscape management for agriculture, rural livelihoods, and ecosystem conservation: An assessment of experience from Latin America and the Caribbean. Landsc. Urban Plan. 2014, 129, 1-11. [CrossRef]

24. Dalgaard, T.; Kjeldsen, C.; Hutchings, N.; Happe, K.; Osuch, A.; Damgaard, M.; Zander, P.; Piorr, A. Multifunctional farming, multifunctional landscapes and rural development. In Multifunctional Land Use; Springer: Berlin/Heidelberg, Germany, 2007; pp. 183-193.

25. Atwell, R.C.; Schulte, L.A.; Westphal, L.M. How to build multifunctional agricultural landscapes in the US Corn Belt: Add perennials and partnerships. Land Use Policy 2010, 27, 1082-1090. [CrossRef] 
26. Huang, J.; Tichit, M.; Poulot, M.; Darly, S.; Li, S.; Petit, C.; Aubry, C. Comparative review of multifunctionality and ecosystem services in sustainable agriculture. J. Environ. Manag. 2015, 149, 138-147. [CrossRef] [PubMed]

27. Burgi, M.; Ali, P.; Chowdhury, A.; Heinimann, A.; Hett, C.; Kienast, F.; Mondal, M.K.; Upreti, B.R.; Verburg, P.H. Integrated Landscape Approach: Closing the Gap between Theory and Application. Sustainability 2017, 9, 1371. [CrossRef]

28. Di Lucia, L.; Usai, D.; Woods, J. Designing landscapes for sustainable outcomes-The case of advanced biofuels. Land Use Policy 2018, 73, 434-446. [CrossRef]

29. Zasada, I.; Häfner, K.; Schaller, L.; Van Zanten, B.T.; Lefebvre, M.; Malak-Rawlikowska, A.; Nikolov, D.; Rodríguez-Entrena, M.; Manrique, R.; Ungaro, F. A conceptual model to integrate the regional context in landscape policy, management and contribution to rural development: Literature review and European case study evidence. Geoforum 2017, 82, 1-12. [CrossRef]

30. Natarajan, L. Socio-spatial learning: A case study of community knowledge in participatory spatial planning. Prog. Plan. 2017, 111, 1-23. [CrossRef]

31. Steinitz, C. A Framework for Geodesign: Changing Geography by Design; Esri: Redlands, CA, USA, 2012.

32. Karrasch, L.; Maier, M.; Kleyer, M.; Klenke, T. Collaborative Landscape Planning: Co-Design of Ecosystem-Based Land Management Scenarios. Sustainability 2017, 9, 1668. [CrossRef]

33. Opdam, P.; Nassauer, J.I.; Wang, Z.F.; Albert, C.; Bentrup, G.; Castella, J.C.; McAlpine, C.; Liu, J.G.; Sheppard, S.; Swaffield, S. Science for action at the local landscape scale. Landsc. Ecol. 2013, 28, 1439-1445. [CrossRef]

34. Slotterback, C.S.; Runck, B.; Pitt, D.G.; Kne, L.; Jordan, N.R.; Mulla, D.J.; Zerger, C.; Reichenbach, M. Collaborative Geodesign to advance multifunctional landscapes. Landsc. Urban Plan. 2016, 156, 71-80. [CrossRef]

35. Campagna, M. Metaplanning: About designing the Geodesign process. Landsc. Urban Plan. 2016, 156, 118-128. [CrossRef]

36. Lee, D.J.; Dias, E.; Scholten, H.J. Geodesign by Integrating Design and Geospatial Sciences; Springer: Cham, Switzerland, 2014; Volume 111.

37. Flaxman, M. Fundamentals of geodesign. In Proceedings of Digital Landscape Architecture; Anhalt University of Applied Science: Bernburg, Germany, 2010; pp. 28-41.

38. Albert, C.; Vargas-Moreno, J.C. Testing geodesign in landscape planning-first results. In Digital Landscape Architecture Conference; Anhalt University of Applied Science: Bernburg, Germany, 2012.

39. Hollstein, L.M. Retrospective and reconsideration: The first 25 years of the Steinitz framework for landscape architecture education and environmental design. Landsc. Urban Plan. 2019, 186, 56-66. [CrossRef]

40. Campagna, M.; Carl, S.; Di Cesare, E.A.; Cocco, C.; Hrishikesh, B.; Tess, C. Collaboration in Planning: The Geodesign Approach; University of Cagliari: Cagliari, Italy, 2016.

41. Wiggering, H.; Müller, K.; Werner, A.; Helming, K. The concept of multifunctionality in sustainable land development. In Sustainable Development of Multifunctional Landscapes; Springer: Dordrecht, The Netherlands, 2003; pp. 3-18.

42. Assessment, M.E. Ecosystems and Human Well-Being; Island Press: Washington, DC, USA, 2005; Volume 5.

43. De Groot, R.; Hein, L. Concept and valuation of landscape functions at different scales. In Multifunctional Land Use; Springer: Berlin/Heidelber, Germany, 2007; pp. 15-36.

44. Emmerson, M.; Morales, M.B.; Onate, J.J.; Batry, P.; Berendse, F.; Liira, J.; Aavik, T.; Guerrero, I.; Bommarco, R.; Eggers, S.; et al. How Agricultural Intensification Affects Biodiversity and Ecosystem Services. Adv. Ecol. Res. 2016, 55, 43-97. [CrossRef]

45. Meehan, T.D.; Werling, B.P.; Landis, D.A.; Gratton, C. Agricultural landscape simplification and insecticide use in the Midwestern United States. Proc. Natl. Acad. Sci. USA 2011, 108, 11500-11505. [CrossRef] [PubMed]

46. Poveda, K.; Martinez, E.; Kersch-Becker, M.F.; Bonilla, M.A.; Tscharntke, T. Landscape simplification and altitude affect biodiversity, herbivory and Andean potato yield. J. Appl. Ecol. 2012, 49, 513-522. [CrossRef]

47. Grab, H.; Danforth, B.; Poveda, K.; Loeb, G. Landscape simplification reduces classical biological control and crop yield. Ecol. Appl. 2018, 28, 348-355. [CrossRef] [PubMed]

48. Otte, A.; Simmering, D.; Wolters, V. Biodiversity at the landscape level: Recent concepts and perspectives for multifunctional land use. Landsc. Ecol. 2007, 22, 639-642. [CrossRef] 
49. Groot, J.C.J.; Jellema, A.; Rossing, W.A.H. Designing a hedgerow network in a multifunctional agricultural landscape: Balancing trade-offs among ecological quality, landscape character and implementation costs. Eur. J. Agron. 2010, 32, 112-119. [CrossRef]

50. Fagerholm, N.; Eilola, S.; Kisanga, D.; Arki, V.; Kayhko, N. Place-based landscape services and potential of participatory spatial planning in multifunctional rural landscapes in Southern highlands, Tanzania. Landsc. Ecol. 2019, 34, 1769-1787. [CrossRef]

51. Rallings, A.M.; Smukler, S.M.; Gergel, S.E.; Mullinix, K. Towards multifunctional land use in an agricultural landscape: A trade-off and synergy analysis in the Lower Fraser Valley, Canada. Landsc. Urban Plan. 2019, 184, 88-100. [CrossRef]

52. Van Zanten, B.T.; Verburg, P.H.; Espinosa, M.; Gomez-y-Paloma, S.; Galimberti, G.; Kantelhardt, J.; Kapfer, M.; Lefebvre, M.; Manrique, R.; Piorr, A.; et al. European agricultural landscapes, common agricultural policy and ecosystem services: A review. Agron. Sustain. Dev. 2014, 34, 309-325. [CrossRef]

53. Chopin, P.; Blazy, J.M.; Guinde, L.; Wery, J.; Dore, T. A framework for designing multi-functional agricultural landscapes: Application to Guadeloupe Island. Agric. Syst. 2017, 157, 316-329. [CrossRef]

54. Fiedler, A.K.; Landis, D.A.; Wratten, S.D. Maximizing ecosystem services from conservation biological control: The role of habitat management. Biol. Control 2008, 45, 254-271. [CrossRef]

55. Gillespie, M.; Wratten, S.D. The importance of viticultural landscape features and ecosystem service enhancement for native butterflies in New Zealand vineyards. J. Insect Conserv. 2012, 16, 13-23. [CrossRef]

56. Van den Belt, M.; Schiele, H.; Forgie, V. Integrated Freshwater Solutions-A New Zealand Application of Mediated Modeling. J. Am. Water Resour. 2013, 49, 669-680. [CrossRef]

57. Dominati, E.; Mackay, A.; Green, S.; Patterson, M. A soil change-based methodology for the quantification and valuation of ecosystem services from agro-ecosystems: A case study of pastoral agriculture in New Zealand. Ecol. Econ. 2014, 100, 119-129. [CrossRef]

58. Dominati, E.J.; Mackay, A.D.; Bouma, J.; Green, S. An Ecosystems Approach to Quantify Soil Performance for Multiple Outcomes: The Future of Land Evaluation? Soil Sci. Soc. Am. J. 2016, 80, 438-449. [CrossRef]

59. Van den Belt, M.; Blake, D. Ecosystem services in New Zealand agro-ecosystems: A literature review. Ecosyst. Serv. 2014, 9, 115-132. [CrossRef]

60. Dominati, E.J.; Maseyk, F.J.F.; Mackay, A.D.; Rendel, J.M. Farming in a changing environment: Increasing biodiversity on farm for the supply of multiple ecosystem services. Sci. Total Environ. 2019, 662, 703-713. [CrossRef]

61. Hermann, A.; Schleifer, S.; Wrbka, T. The concept of ecosystem services regarding landscape research: A review. Living Rev. Landsc. Res. 2011, 5, 1-37. [CrossRef]

62. Kienast, F.; Wildi, O.; Ghosh, S. A Changing World: Challenges for Landscape Research; Springer Science \& Business Media: Dordrecht, The Netherlands, 2007; Volume 8.

63. Nyerges, T.; Ballal, H.; Steinitz, C.; Canfield, T.; Roderick, M.; Ritzman, J.; Thanatemaneerat, W. Geodesign dynamics for sustainable urban watershed development. Sustain. Cities Soc. 2016, 25, 13-24. [CrossRef]

64. Newman, G.; Malecha, M.; Yu, S.Y.; Qiao, Z.X.; Horney, J.A.; Lee, J.; Kim, Y.J.; Lee, R.J.; Berke, P. Integrating a resilience scorecard and landscape performance tools into a Geodesign process. Landsc. Res. 2019. [CrossRef]

65. Gu, Y.; Deal, B. Coupling systems thinking and geodesign processes in land-use modelling, design, and planning. J. Dig. Landsc. Arch. 2018, 3, 51-59.

66. Pettit, C.; Hawken, S.; Ticzon, C.; Nakanishi, H. Geodesign-A Tale of Three Cities. In Proceedings of the International Conference on Computers in Urban Planning and Urban Management, Adelaide, Australia, 11-14 July 2017; pp. 139-161.

67. Zandvoort, M.; Van der Vlist, M.J. The Multi-Layer Safety Approach and Geodesign: Exploring Exposure and Vulnerability to Flooding. In Geodesign by Integrating Design and Geospatial Sciences; Springer: Cham, Switzerland, 2014; pp. 133-148.

68. Sophronides, P.; Steenbruggen, J.; Scholten, H.; Giaoutzi, M. Geodesign the multi-layered water safety. Res. Urban Ser. 2016, 4, 113-138.

69. Xie, Y.Q.; Runck, B.C.; Shekhar, S.; Kne, L.; Mulla, D.; Jordan, N.; Wiringa, P. Collaborative Geodesign and Spatial Optimization for Fragmentation-Free Land Allocation. ISPRS Int. J. Geo-Inf. 2017, 6, 226. [CrossRef]

70. Raumer, H.-G.S.-v.; Jörg, J.; Alfiky, M. Respecting the Role of Agriculture for an Untegrated Landscape Development at the Urban-rural Fringe Using Geodesign Tools. J. Digit. Landsc. Archit. 2016, 327-336. [CrossRef] 
71. Jordan, N.R.; Mulla, D.J.; Slotterback, C.; Runck, B.; Hays, C. Multifunctional agricultural watersheds for climate adaptation in Midwest USA: Commentary. Renew. Agric. Food Syst. 2018, 33, 292-296. [CrossRef]

72. Shannon McElvaney, D.R. Geodesign and the Future of Planning. Available online: https://www.planning. org/publications/document/9121411/ (accessed on 27 March 2020).

73. Esri GeoDesign Team. GeoDesign Defined: A Framework and Process for a More Sustainable World. Available online: https://storymaps.arcgis.com/stories/ebef9d80309b4812bea11e2f39e3d357 (accessed on 27 March 2020).

74. ESRI. Geodesign Summit 2019. Available online: https://www.esri.com/videos/?event= 5cb9e8b83d9d867608dcab88\&title=Geodesign\%20Summit (accessed on 20 November 2019).

75. Minnesota, U.O. Seven Mile Creek Geodesign. Available online: https://maps.umn.edu/geodesign/ (accessed on 23 January 2020).

76. Iowa State University. Geodesigning the Farm of the Future: Parameterizing for Climate Change. Available online: https://www.youtube.com/watch?time_continue $=417 \& v=\ln$ Xomp9Pf-I\&feature=emb_title (accessed on 20 April 2020).

77. Claessens, L.; Schoorl, J.; Veldkamp, A. Modelling the location of shallow landslides and their effects on landscape dynamics in large watersheds: An application for Northern New Zealand. Geomorphology 2007, 87, 16-27. [CrossRef]

78. Borrelle, S.B.; Buxton, R.T.; Jones, H.P.; Towns, D.R. A GIS-based decision-making approach for prioritizing seabird management following predator eradication. Restor. Ecol. 2015, 23, 580-587. [CrossRef]

79. Longdill, P.C.; Healy, T.R.; Black, K.P. An integrated GIS approach for sustainable aquaculture management area site selection. Ocean Coast. Manag. 2008, 51, 612-624. [CrossRef]

80. Singh, S.K.; Zeddies, M.; Shankar, U.; Griffiths, G.A. Potential groundwater recharge zones within New Zealand. Geosci. Front. 2019, 10, 1065-1072. [CrossRef]

81. MacMillan, H.; Moore, A.B.; Augé, A.A.; Chilvers, B.L. GIS-based multi-criteria analysis of breeding habitats for recolonising species: New Zealand sea lions. Ocean Coast. Manag. 2016, 130, 162-171. [CrossRef]

82. Eagle Technology. Geodesign-Ancient Concept, Universal Applications, Modern Tools. Available online: https://www.eagle.co.nz/geodesign (accessed on 27 August 2019).

83. Moore, A.; Johnson, M.; Gbolagun, J.; Miller, A.; Rombouts, A.; van der Ven, L.; Lord, J.; Coutts, S.; Pagan, M.; Hall, G.B. Integrating agroecology and sustainable tourism: Applying geodesign to farm management in Aotearoa New Zealand. J. Sustain. Tour 2018, 26, 1543-1561. [CrossRef]

84. Eikelboom, T.; Janssen, R. Collaborative use of geodesign tools to support decision-making on adaptation to climate change. Mitig. Adapt. Strat. Glob. Chang. 2017, 22, 247-266. [CrossRef] [PubMed]

85. Hansen, R.; Pauleit, S. From multifunctionality to multiple ecosystem services? A conceptual framework for multifunctionality in green infrastructure planning for urban areas. AMBIO 2014, 43, 516-529. [CrossRef] [PubMed]

86. Von Haaren, C.; Warren-Kretzschmar, B.; Milos, C.; Werthmann, C. Opportunities for design approaches in landscape planning. Landsc. Urban Plan. 2014, 130, 159-170. [CrossRef]

87. Huang, L.; Xiang, W.N.; Wu, J.G.; Traxler, C.; Huang, J.Z. Integrating GeoDesign with Landscape Sustainability Science. Sustainability 2019, 11, 833. [CrossRef]

88. Li, W.M.; Milburn, L.A. The evolution of geodesign as a design and planning tool. Landsc. Urban Plan. 2016, 156, 5-8. [CrossRef]

89. Kastuari, A.; Suwardhi, D.; Hanan, H.; Wikantika, K. State of the art of the landscape architecture spatial data model from a geospatial perspective. In Proceedings of the 11th 3D Geoinfo Conference, Athens, Greece, 20-21 October 2016.

90. ESRI. Geodesign in Practice: Designing a Better World. 2013. Available online: https://www.esri.com/ \{\}/ media/Files/Pdfs/library/ebooks/geodesign-in-practice.pdf (accessed on 10 December 2019).

91. Soini, K. Exploring human dimensions of multifunctional landscapes through mapping and map-making. Landsc. Urban Plan. 2001, 57, 225-239. [CrossRef]

92. Blaschke, P.M.; Trustrum, N.A.; Derose, R.C. Ecosystem Processes and Sustainable Land-Use in New-Zealand Steeplands. Agric. Ecosyst. Environ. 1992, 41, 153-178. [CrossRef]

93. Molloy, L. Soils in the New Zealand Landscape: The Living Mantle; Kings Time Printing Press Ltd.: Hong Kong, China; New Zealand Society of Soil Science: Lincoln, New Zealand, 1998; p. 253. 
94. Lynn, I.; Manderson, A.; Page, M.; Harmsworth, G.; Eyles, G.; Douglas, G.; Mackay, A.; Newsome, P. Land use capability survey handbook: A New Zealand handbook for the classification of land. In Landcare Research; AgResearch: Lincoln, New Zealand, 2009.

95. Jones, H.; Clough, P.; Hock, B.; Phillips, C. Economic costs of hill country erosion and benefits of mitigation in New Zealand: Review and recommendation of approach. In Scion; Forest Res. Inst.: Rotorua, New Zealand, 2008.

96. Hedley, C.; Manderson, A.; Mudge, P.; Roudier, P.; Fraser, S.; Parfitt, R.; Smaill, S.; Schipper, L.; Kelliher, F. Improved Measurements of Hill Country Soil Carbon to Assist Carbon Change Studies; Ministry for Primary Industries: Wellington, New Zealand, 2015.

97. Kerr, G. Why a hill country symposium? In Proceedings of Hill Country Symposium; NZ Grassland Association: Rotorua, New Zealand, 2016; pp. 7-9.

98. Beef and Lamb. 2018 Annual Report. Available online: https://beeflambnz.com/sites/default/files/B\%2BLNZ_ AR_2018_web-compressed.pdf (accessed on 26 August 2019).

99. Norton, D.; Pannell, J. Desk-Top Assessment of Native Vegetation on New Zealand Sheep and Beef Farms; School of Forestry, University of Canterbury and Institute for Applied Ecology, Auckland University of Technology: Auckland, New Zealand, 2018; pp. 1-32.

100. Beef and Lamb. Hill Country Sheep and Beef Farms. Available online: https://beeflambnz.com/knowledgehub/PDF/FS077-hill-country-sheep-beef (accessed on 10 August 2019).

101. Rutledge, D.T.; Cameron, M.P.; Briggs, C.M.; Elliott, S.; Fenton, T.; Hurkens, J.; McDonald, G.; McBride, G.; Phyn, D.; Poot, J.; et al. WISE: Waikato Integrated Scenario Explorer: Technical Specifications, Version 1.4; Waikato Regional Council: Hamilton, New Zealand, 2016.

102. Phillips, C.; Marden, M.; Basher, L.R. Geomorphology and forest management in New Zealand's erodible steeplands: An overview. Geomorphology 2018, 307, 107-121. [CrossRef]

103. Harding, J.S. Historic deforestation and the fate of endemic invertebrate species in streams. N. Z. J. Mar. Fresh 2003, 37, 333-345. [CrossRef]

104. Basher, L.R. Erosion processes and their control in New Zealand. In Proceedings of Ecosystem Services in New Zealand-Conditions and Trends; Lincoln University: Lincoln, New Zealand, 2013; pp. 363-374.

105. Ministry for Primary Industries. Funding Programmes for Tree Planting and Research. Available online: https://www.mpi.govt.nz/funding-and-programmes/forestry/ (accessed on 10 December 2019).

106. Marden, M.; Herzig, A.; Basher, L. Erosion process contribution to sediment yield before and after the establishment of exotic forest: Waipaoa catchment, New Zealand. Geomorphology 2014, 226, 162-174. [CrossRef]

107. Evison, D. Climate Change Mitigation in New Zealand-What is the Role of New Planted Forests? University of Canterbury: Christchurch, New Zealand, 2018.

108. Yao, R.T.; Barry, L.E.; Wakelin, S.J.; Harrison, D.R.; Magnard, L.A.; Payn, T.W. Planted Forests; Landcare Research: Lincoln, New Zealand, 2013; pp. 62-78.

109. Lang, S. Future Challenges and Opportunities for Hill Country Farming on the East Coast. Available online: https://ruralleaders.co.nz/files/Lang_S_Future_challenges_and_opportunities_for_hill_country_ farming_on_the_East_Coast_Final.pdf (accessed on 15 August 2019).

110. Funk, J.M.; Field, C.B.; Kerr, S.; Daigneault, A. Modeling the impact of carbon farming on land use in a New Zealand landscape. Environ. Sci. Policy 2014, 37, 1-10. [CrossRef]

111. Funk, J.; Kerr, S. Restoring forests through carbon farming on Māori land in New Zealand/Aotearoa. Mt. Res. Dev. 2007, 27, 202-206. [CrossRef]

112. Ministry for the Environment and Stats NZ. New Zealand's Environmental Reporting Series: Our Land 2018; Ministry for the Environment and Stats NZ: Wellington, New Zealand, 2018.

113. McIvor, I.; Douglas, G.; Dymond, J.; Eyles, G.; Marden, M. Pastoral Hill Slope Erosion in New Zealand and the Role of Poplar and Willow Trees in Its Reduction. Available online: https: //books.google.ae/books?hl=zh-CN\&lr=\&id=SheQDwAAQBAJ\&oi=fnd\&pg=PA257\&dq=Pastoral+Hill+ Slope+Erosion+in+New+Zealand +and +the+Role+of+Poplar+and+Willow+Trees+in+Its+Reduction\& ots=MBxa6CXS46\&sig=Bz-Y4BLXDFe8yE3unK7cJvIJTyM\&redir_esc=y\#v=onepage\&q\&f=false $($ accessed on 20 May 2020).

114. Rodda, H.; Stroud, M.; Shankar, U.; Thorrold, B. A GIS based approach to modelling the effects of land-use change on soil erosion in New Zealand. Soil Use Manag. 2001, 17, 30-40. [CrossRef] 
115. Marden, M. Effectiveness of reforestation in erosion mitigation and implications for future sediment yields, East Coast catchments, New Zealand: A review. N. Z. Geogr. 2012, 68, 24-35. [CrossRef]

116. Ministry for the Environment. Estimated Long-Term Soil Erosion. Available online: http://archive.stats.govt.nz/browse_for_stats/environment/environmental-reporting-series/environmentalindicators/Home/Land/long-term-soil-erosion.aspx (accessed on 23 August 2019).

117. National Water and Soil Conservation Organisation. Wise Land Use and Community Development; National Water and Soil Conservation Organisation: Wellington, New Zealand, 1970.

118. Piegay, H.; Walling, D.E.; Landon, N.; He, Q.P.; Liebault, F.; Petiot, R. Contemporary changes in sediment yield in an alpine mountain basin due to afforestation (the upper Drome in France). Catena 2004, 55, 183-212. [CrossRef]

119. Nottage, R.; Wilcocks, L.; Lee, J.; Burke, C.; Kalaugher, E.; Roche, J.; Beukes, P.; Lieffering, M.; Newton, P.; Li, F. Impacts of Climate Change on Land-Based Sectors and Adaptation Options; Ministry for Primary Industries: Wellington, New Zealand, 2012.

120. Pearce, H.G.; Clifford, V. Fire weather and climate of New Zealand. N. Z. J. For. 2008, 53, 13-18.

121. Mullan, B.; Porteous, A.; Wratt, D.; Hollis, M. Changes in Drought Risk with Climate Change; National Institute of Water \& Atmospheric Research Ltd.: Wellington, New Zealand, 2005.

122. Moot, D.J.; Mills, A.; Pollock, K.M. Natural resources for Canterbury agriculture. In Proceedings of the New Zealand Grassland Association; NZ Grassland Association: Dunedin, New Zealand, 2006.

123. Hendy, J.; Kerr, S.; Halliday, A.; Owen, S.; Deans, N.; Dickie, B.; Hale, J. Drought and Climate Change Adaptation: Impacts and Projections; Motu Economic and Public Policy Research: Wellington, New Zealand, 2018.

124. Grafton, M.; Manning, M. Establishing a Risk Profile for New Zealand Pastoral Farms. Agriculture 2017, 7, 81. [CrossRef]

125. Climate Change Adaptation Technical Working Group. Adapting to Climate Change in New Zealand; Climate Change Adaptation Technical Working Group, Ministry for the Environment: Wellington, New Zealand, 2017.

126. New Zealand Agricultural Greenhouse Gas Research Centre. Impacts of Global Climate Change on New Zealand Agriculture. Available online: https://www.nzagrc.org.nz/fact-sheets,listing,94,impacts-of-globalclimate-change-on-new-zealand-agriculture.html (accessed on 6 May 2019).

127. McDonald, H.; Kerr, S. Why do New Zealanders care about agricultural emissions? Policy Q. 2012, 8. [CrossRef]

128. Ministry for the Environment. New Zealand Action on Climate Change.; Ministry for the Environment: Wellington, New Zealand, 2016.

129. Cortés-Acosta, S.; David, A.; Fleming, L.H.; Lou, E.; Owen, S.; Small, B. Identifying Barriers to Adoption of "no-cost" Greenhouse Gas Mitigation Practices in Pastoral Systems; Motu Working Paper 19-10; Motu Economic and Public Policy Research: Wellington, New Zealand, 2019.

130. Haggerty, J.; Campbell, H.; Morris, C. Keeping the stress off the sheep? Agricultural intensification, neoliberalism, and 'good'farming in New Zealand. Geoforum 2009, 40, 767-777. [CrossRef]

131. Dodd, M.; Wedderburn, M.; Parminter, T.; Thorrold, B.; Quinn, J. Transformation toward agricultural sustainability in New Zealand hill country pastoral landscapes. Agric. Syst. 2008, 98, 95-107. [CrossRef]

132. Peden, R. Farming in the Economy-The Golden Years, 1950s to 1980s'. Te Ara-The Encyclopedia of New Zealand. Available online: https://teara.govt.nz/en/farming-in-the-economy/page-7 (accessed on 5 April 2020).

133. Moller, H.; MacLeod, C.J.; Haggerty, J.; Rosin, C.; Blackwell, G.; Perley, C.; Meadows, S.; Weller, F.; Gradwohl, M. Intensification of New Zealand agriculture: Implications for biodiversity. N. Z. J. Agric. Res. 2008, 51, 253-263. [CrossRef]

134. Parfitt, R.; Mackay, A.; Ross, D.; Budding, P. Effects of soil fertility on leaching losses of N, P and C in hill country. N. Z. J. Agric. Res. 2009, 52, 69-80. [CrossRef]

135. Betterige, K.; Kawamura, K.; Costall, D.; Ganesh, S.; Luo, D.; Koolaard, J.; Yoshitoshi, R. Intensive Livestock Farming on New Zealand Hill Country Farms Creates Critical Source Areas of Potential Pollution. J. Integr. Field Sci. 2017, 14, 103.

136. Parliamentary Commissioner for the Environment. Climate Change and Agriculture: Understanding the Biological Greenhouse Gases; Parliamentary Commissioner for the Environment: Wellington, New Zealand, 2016. 
137. Swaffield, S. Sustainability practices in New Zealand agricultural landscapes under an open market policy regime. Landsc. Res. 2014, 39, 190-204. [CrossRef]

138. Tayler, M.; Donnelly, L.; Frater, P.; Stocker, N. Lorne Peak Station-achieving sustainable profitability in challenging Southland hill country. In Proceedings of Hill Country Symposium-Grassland Research Practice Series; NZ Grassland Association: Rotorua, New Zealand, 2016; pp. 101-108.

139. Ford, J.G.; Ford, C.M. Highlands Station-A story of economic and environmental sustainability. In Proceedings of Hill Country Symposium-Grassland Research and Practice Series; NZ Grassland Association: Rotorua, New Zealand, 2016; pp. 149-150.

140. Hoogendoorn, C.; Lambert, M.; Devantier, B.; Theobald, P.; Park, Z. Nitrogen fertiliser application rates and nitrogen leaching in intensively managed sheep grazed hill country pastures in New Zealand. N. Z. J. Agric. Res. 2017, 60, 154-172. [CrossRef]

141. Fraser, D.; Vesely, E. Connecting north island hill country farmers nutrient requirements with soil mapping units. In Proceedings of FLRC Workshop; Massey Univeristy; Massey Univeristy: Palmerston North, New Zealand, 2011.

142. White, T.; Snow, V.; King, W.M. Intensification of New Zealand beef farming systems. Agric. Syst. 2010, 103, 21-35. [CrossRef]

143. Todd, J.H.; Malone, L.A.; Benge, J.; Poulton, J.; Barraclough, E.I.; Wohlers, M.W. Relationships between management practices and ground-active invertebrate biodiversity in New Zealand kiwifruit orchards. Agric. For. Entomol. 2016, 18, 11-21. [CrossRef]

144. Sandhu, H.S.; Wratten, S.D.; Cullen, R. Organic agriculture and ecosystem services. Environ. Sci. Policy 2010, 13, 1-7. [CrossRef]

145. Sandhu, H.S.; Wratten, S.D.; Cullen, R.; Case, B. The future of farming: The value of ecosystem services in conventional and organic arable land. An experimental approach. Ecol. Econ. 2008, 64, 835-848. [CrossRef]

146. Hahner, J.L.; Robinson, B.H.; Zhong, H.T.; Dickinson, N.M. The Phytoremediation Potential of Native Plants on New Zealand Dairy Farms. Int. J. Phytoremediat. 2014, 16, 719-734. [CrossRef] [PubMed]

147. Struik, P.C.; Kuyper, T.W. Sustainable intensification in agriculture: The richer shade of green. A review. Agron. Sustain. Dev. 2017, 37, 39. [CrossRef]

148. Gillingham, A.; Morton, J.; Gray, M. The role of differential fertiliser application in sustainable management of hill pastures. In Proceedings of the New Zealand Grassland Association; NZ Grassland Association: Palmerston North, New Zealand, 2003; pp. 253-257.

149. Yadav, R.; Pathak, G.S. Young consumers' intention towards buying green products in a developing nation: Extending the theory of planned behavior. J. Clean. Prod. 2016, 135, 732-739. [CrossRef]

150. Ghvanidze, S.; Velikova, N.; Dodd, T.H.; Oldewage-Theron, W. Consumers' environmental and ethical consciousness and the use of the related food products information: The role of perceived consumer effectiveness. Appetite 2016, 107, 311-322. [CrossRef] [PubMed]

151. McDermott, A.; Scrimgeour, F. Consumers, farmers and the future of New Zealand hill country farming. In Proceedings of Hill Country Symposium; Grassland Research and Practice Series; NZ Grassland Association: Rotorua, New Zealand, 2016; pp. 95-100.

152. Fennessy, P.; Glennie, S.; McCorkindale, A. Innovations behind the farm gate that will influence performance of hill farming. In Proceedings of Hill Country Symposium: Grassland Research Practice Series; NZ Grassland Association: Rotorua, New Zealand, 2016; pp. 15-20.

153. Samarasinghe, O.; Greenhalgh, S. Economic and Bio-Physical Models for New Zealand; Landcare Research: Lincoln, New Zealand, 2011.

154. Beef and Lamb. Land and Environment Planning. Available online: https://beeflambnz.com/knowledgehub/PDF/land-and-environment-plan-brochure (accessed on 8 August 2019).

155. McNally, S.R.; Beare, M.H.; Curtin, D.; Meenken, E.D.; Kelliher, F.M.; Calvelo Pereira, R.; Shen, Q.; Baldock, J. Soil carbon sequestration potential of permanent pasture and continuous cropping soils in New Zealand. Glob. Chang. Biol. 2017, 23, 4544-4555. [CrossRef]

156. Dymond, J.R.; Vale, S.S. An event-based model of soil erosion and sediment transport at the catchment scale. Geomorphology 2018, 318, 240-249. [CrossRef]

157. Burkitt, L.; Bretherton, M.; Singh, R.; Hedley, M. Comparing Nutrient Loss Predictions Using OVERSEER and Stream Water Quality in a Hill Country Sub-Catchment. In Proceedings of Integrated Nutrient Water Management for Sustainable Farming; Massey University: Palmerston North, New Zealand, 2016; p. 9. 
158. Higham, C.D.; Horne, D.; Singh, R.; Kuhn-Sherlock, B.; Scarsbrook, M.R. Water use on nonirrigated pasture-based dairy farms: Combining detailed monitoring and modeling to set benchmarks. J. Dairy Sci. 2017, 100, 828-840. [CrossRef]

159. Rendel, J.; Mackay, A.; Smale, P. The value of legumes to a Whanganui hill country farm. J. N. Z. Grassl. 2017, 79, 27-34.

160. Keller, E.; Baisden, W.; Timar, L. Adapting the Biome-BGC model to New Zealand pastoral agriculture: Climate change and land-use change. In Proceedings of AGU Fall Meeting Abstracts; American Geophysical Union: Washington, DC, USA, 2011.

161. Risk, J.; Old, A.; Peyroux, G.; Brown, M.; Yoswara, H.; Wheeler, D.; Lucci, G.; McDowell, R. MITAGATORTM-In action solutions for managing Nitrogen, Phosphorus, sediment and E. coli loss. In Proceedings of FLRC Workshop; Massey Univeristy: Palmerston North, New Zealand, 2011.

162. Bryant, J.; Ogle, G.; Marshall, P.; Glassey, C.; Lancaster, J.; Garcia, S.; Holmes, C. Description and evaluation of the Farmax Dairy Pro decision support model. N. Z. J. Agric. Res. 2010, 53, 13-28. [CrossRef]

163. Morgan, F.J.; Daigneault, A.J. Estimating Impacts of Climate Change Policy on Land Use: An Agent-Based Modelling Approach. PLoS ONE 2015, 10, e0127317. [CrossRef] [PubMed]

164. Landcare Research. New Zealand Forest and Agriculture Regional Model (NZ-FARM); Landcare Research: Lincoln, New Zealand, 2013.

165. AgResearch. It's Everybody's Business: Whole Farm Plans-A Vehicle for Implementing Policy; AgResearch: Hamilton, New Zealand, 2016.

166. Cameron, D. Sustaining the productivity of New Zealand's hill country-A land manager's view. In Proceedings of Hill Country Symposium: Grassland Research Practice Series; NZ Grassland Association: Rotorua, New Zealand, 2016; pp. 151-156.

167. Tran, T.V.; Tran, D.X.; Myint, S.W.; Huang, C.-y.; Pham, H.V.; Luu, T.H.; Vo, T.M. Examining spatiotemporal salinity dynamics in the Mekong River Delta using Landsat time series imagery and a spatial regression approach. Sci. Total Environ. 2019, 687, 1087-1097. [CrossRef] [PubMed]

168. Stevens, D.; Casey, M.; Cousins, K. Farming systems research: Purpose, history and impact in New Zealand hill country. In Proceedings of Hill Country Symposium: Grassland Research Practice Series; NZ Grassland Association: Rotorua, New Zealand, 2016; pp. 67-86.

169. Van den Belt, M.; Forgie, V.; Bremer, S.; McDonald, G.; Montes de Oca, O.; Joy, M. Modelling Tools for Integrated, Adaptive Management: A Case Study of New Zealand Regional Authorities; Massey University: Palmerston North, New Zealand, 2010.

170. Synge, K.; MacKay, A.; Palmer, A. An evaluation of the Land and Environment Planning Toolkit for advancing soil and nutrient management on sheep and beef farms. In Proceedings of the New Zealand Grassland Association; NZ Grassland Association: Tauranga, New Zealand, 2013; pp. 91-96.

171. Sugumaran, R.; Degroote, J. Spatial Decision Support Systems: Principles and Practices; Crc Press, Taylor \& Francis Group: Boca Raton, FL, USA, 2010.

172. McGlone, M. The Polynesian settlement of New Zealand in relation to environmental and biotic changes. N. Z. J. Ecol. 1989, 12, 115-129.

173. Ministry for the Environment. Pressures on the Land; Ministry for the Environment: Wellington, New Zealand, 1997.

174. Beef and Lamb. Farm Facts 2018. Available online: https://beeflambnz.com/knowledge-hub/PDF/ compendium-farm-facts (accessed on 18 August 2019).

175. Rodriguez, J.P.; Beard, T.D.; Bennett, E.M.; Cumming, G.S.; Cork, S.J.; Agard, J.; Dobson, A.P.; Peterson, G.D. Trade-offs across space, time, and ecosystem services. Ecol. Soc. 2006, 11, 28. [CrossRef]

176. Caruso, B.S.; O'Sullivan, A.D.; Faulkner, S.; Sherratt, M.; Clucas, R. Agricultural Diffuse Nutrient Pollution Transport in a Mountain Wetland Complex. Water Air Soil Pollut. 2013, 224. [CrossRef]

177. Schon, N.; Mackay, A.; Gray, R.; Minor, M. Influence of phosphorus inputs and sheep treading on soil macrofauna and mesofauna in hill pastures. N. Z. J. Agric. Res. 2011, 54, 83-96. [CrossRef]

178. Laliberte, E.; Tylianakis, J.M. Cascading effects of long-term land-use changes on plant traits and ecosystem functioning. Ecology 2012, 93, 145-155. [CrossRef] 
179. Wakelin, S.A.; Barratt, B.I.; Gerard, E.; Gregg, A.L.; Brodie, E.L.; Andersen, G.L.; DeSantis, T.Z.; Zhou, J.; He, Z.; Kowalchuk, G.A. Shifts in the phylogenetic structure and functional capacity of soil microbial communities follow alteration of native tussock grassland ecosystems. Soil Biol. Biochem. 2013, 57, 675-682. [CrossRef]

180. Landis, D.A. Designing agricultural landscapes for biodiversity-based ecosystem services. Basic Appl. Ecol. 2017, 18, 1-12. [CrossRef]

181. Jorgensen, S.E.; Fath, B.D. Encyclopedia of Ecology; Elsevier, B.V: Oxford, UK, 2008.

182. Selman, P. Planning for landscape multifunctionality. Sustainability 2009, 5, 45-52. [CrossRef]

183. Killion, A.K.; Dixon, A.; Gilbert, J.; Torralba, M.; Greiner, P.T.; Behrer, A.P. Designing spatiotemporal multifunctional landscapes to support dynamic wildlife conservation. J. Land Use Sci. 2018, 13, 615-630. [CrossRef]

184. Lovell, S.T.; Taylor, J.R. Supplying urban ecosystem services through multifunctional green infrastructure in the United States. Landsc. Ecol. 2013, 28, 1447-1463. [CrossRef]

185. Biggs, R.; Schlüter, M.; Biggs, D.; Bohensky, E.L.; BurnSilver, S.; Cundill, G.; Dakos, V.; Daw, T.M.; Evans, L.S.; Kotschy, K. Toward principles for enhancing the resilience of ecosystem services. Annu. Rev. Environ. Resour. 2012, 37, 421-448. [CrossRef]

186. Scherr, S.J.; McNeely, J.A. Biodiversity conservation and agricultural sustainability: Towards a new paradigm of 'ecoagriculture' landscapes. Philos. Trans. R. Soc. B 2008, 363, 477-494. [CrossRef]

187. Kato, S.; Ahern, J. Multifunctional landscapes as a basis for sustainable landscape development. J. Jpn. Inst. Landsc. Archit. 2009, 72, 799-804. [CrossRef]

188. Kremen, C.; Iles, A.; Bacon, C. Diversified farming systems: An agroecological, systems-based alternative to modern industrial agriculture. Ecol. Soc. 2012, 17, 44. [CrossRef]

189. Cumming, G.S.; Buerkert, A.; Hoffmann, E.M.; Schlecht, E.; von Cramon-Taubadel, S.; Tscharntke, T. Implications of agricultural transitions and urbanization for ecosystem services. Nature 2014, 515, 50-57. [CrossRef]

190. Kirchner, M.; Schmidt, J.; Kindermann, G.; Kulmer, V.; Mitter, H.; Prettenthaler, F.; Rüdisser, J.; Schauppenlehner, T.; Schönhart, M.; Strauss, F. Ecosystem services and economic development in Austrian agricultural landscapes - the impact of policy and climate change scenarios on trade-offs and synergies. Ecol. Econ. 2015, 109, 161-174. [CrossRef]

191. Ahern, J. From Landscape Research to Landscape Planning. In Aspects of Integration, Education Application; Springer: Dordrecht, The Netherlands, 2006; pp. 119-131.

192. Dallimer, M.; Strange, N. Why socio-political borders and boundaries matter in conservation. Trends Ecol. Evol. 2015, 30, 132-139. [CrossRef]

193. Bergsten, A.; Galafassi, D.; Bodin, Ö. The problem of spatial fit in social-ecological systems: Detecting mismatches between ecological connectivity and land management in an urban region. Ecol. Soc. 2014, 19, 6. [CrossRef]

194. Schonewald, C.M. Introduction to boundary space. Complexity 2000, 6, 41-57. [CrossRef]

195. NZ Landcare Trust. Catchment Groups. Available online: https://www.landcare.org.nz/completed-projectitem/catchment-groups (accessed on 12 December 2019).

196. Beef and Lamb. Catchment Community Group Programme. Available online: https://beeflambnz.com/yourlevies-work/community-catchment-group-programme (accessed on 14 December 2019).

197. Cerretelli, S.; Poggio, L.; Gimona, A.; Yakob, G.; Boke, S.; Habte, M.; Coull, M.; Peressotti, A.; Black, H. Spatial assessment of land degradation through key ecosystem services: The role of globally available data. Sci. Total Environ. 2018, 628, 539-555. [CrossRef] [PubMed]

198. Arowolo, A.O.; Deng, X.; Olatunji, O.A.; Obayelu, A.E. Assessing changes in the value of ecosystem services in response to land-use/land-cover dynamics in Nigeria. Sci. Total Environ. 2018, 636, 597-609. [CrossRef]

199. Yi, H.; Güneralp, B.; Filippi, A.M.; Kreuter, U.P.; Güneralp, İ. Impacts of land change on ecosystem services in the San Antonio River Basin, Texas, from 1984 to 2010. Ecol. Econ. 2017, 135, 125-135. [CrossRef]

200. Crespin, S.J.; Simonetti, J.A. Loss of ecosystem services and the decapitalization of nature in El Salvador. Ecosyst. Serv. 2016, 17, 5-13. [CrossRef]

201. Mendoza-González, G.; Martínez, M.L.; Lithgow, D.; Pérez-Maqueo, O.; Simonin, P. Land use change and its effects on the value of ecosystem services along the coast of the Gulf of Mexico. Ecol. Econ. 2012, 82, $23-32$. [CrossRef] 
202. Kreuter, U.P.; Harris, H.G.; Matlock, M.D.; Lacey, R.E. Change in ecosystem service values in the San Antonio area, Texas. Ecol. Econ. 2001, 39, 333-346. [CrossRef]

203. Polasky, S.; Nelson, E.; Pennington, D.; Johnson, K.A. The impact of land-use change on ecosystem services, biodiversity and returns to landowners: A case study in the state of Minnesota. Environ. Resour. Econ. 2011, 48, 219-242. [CrossRef]

204. Cabral, P.; Feger, C.; Levrel, H.; Chambolle, M.; Basque, D. Assessing the impact of land-cover changes on ecosystem services: A first step toward integrative planning in Bordeaux, France. Ecosyst. Serv. 2016, 22, 318-327. [CrossRef]

205. Maestre, F.T.; Quero, J.L.; Gotelli, N.J.; Escudero, A.; Ochoa, V.; Delgado-Baquerizo, M.; García-Gómez, M.; Bowker, M.A.; Soliveres, S.; Escolar, C. Plant species richness and ecosystem multifunctionality in global drylands. Science 2012, 335, 214-218. [CrossRef]

206. Maseyk, F.J.; Dominati, E.J.; Mackay, A.D. Change in ecosystem service provision within a lowland dairy landscape under different riparian margin scenarios. Int. J. Biodivers. Sci. Ecosyst. Serv. Manag. 2018, 14, 17-31. [CrossRef]

207. Ausseil, A.G.; Herzig, A.; Dymond, J. Optimising Land Use for Multiple Ecosystem Services Objectives: A Case Study in the WaitakiCatchment, New Zealand. In Proceedings of 6th International Congress on Environmental Modelling and Software; Helmholtz Centre for Environmental Research: Leipzig, Germany, 2012.

208. Willemen, L. Mapping and Modelling Multifunctional Landscapes; Wageningen University: Wageningen, The Netherlands, 2010.

209. Muir, R. The Evaluation of Landscape. In Approaches to Landscape; Palgrave: London, UK, 1999; pp. $182-211$.

210. Wu, J. Landscape sustainability science: Ecosystem services and human well-being in changing landscapes. Landsc. Ecol. 2013, 28, 999-1023. [CrossRef]

211. Baños-González, I.; Martínez-Fernández, J.; Esteve-Selma, M. Using dynamic sustainability indicators to assess environmental policy measures in Biosphere Reserves. Ecol. Indic. 2016, 67, 565-576. [CrossRef]

212. Albert, C.; Galler, C.; Hermes, J.; Neuendorf, F.; Von Haaren, C.; Lovett, A. Applying ecosystem services indicators in landscape planning and management: The ES-in-Planning framework. Ecol. Indic. 2016, 61, 100-113. [CrossRef]

213. Niemeijer, D.; De Groot, R.S. A conceptual framework for selecting environmental indicator sets. Ecol. Indic. 2008, 8, 14-25. [CrossRef]

214. Heink, U.; Hauck, J.; Jax, K.; Sukopp, U. Requirements for the selection of ecosystem service indicators-The case of MAES indicators. Ecol. Indic. 2016, 61, 18-26. [CrossRef]

215. Almenar, J.B.; Rugani, B.; Geneletti, D.; Brewer, T. Integration of ecosystem services into a conceptual spatial planning framework based on a landscape ecology perspective. Landsc. Ecol. 2018, 33, 2047-2059. [CrossRef]

216. Ekroos, J.; Olsson, O.; Rundlöf, M.; Wätzold, F.; Smith, H.G. Optimizing agri-environment schemes for biodiversity, ecosystem services or both? Biol. Conserv. 2014, 172, 65-71. [CrossRef]

217. Pohekar, S.; Ramachandran, M. Application of multi-criteria decision-making to sustainable energy planning-A review. Renew. Sustain. Energy Rev. 2004, 8, 365-381. [CrossRef]

218. Bretagnolle, V.; Berthet, E.; Gross, N.; Gauffre, B.; Plumejeaud, C.; Houte, S.; Badenhausser, I.; Monceau, K.; Allier, F.; Monestiez, P.; et al. Towards sustainable and multifunctional agriculture in farmland landscapes: Lessons from the integrative approach of a French LTSER platform. Sci. Total Environ. 2018, 627, 822-834. [CrossRef]

219. Kimberly, A. Essential of Landscape Ecology; Oxford University Press: Oxford, UK, 2019.

220. Milestad, R.; Björklund, J. Strengthening the adaptive capacity of rural communities: Multifunctional farms and village action groups. In Proceedings of the 8th European IFSA Symposium, Clermont-Ferrand, France, 6-10 July 2008; pp. 6-10.

221. Hassink, J.; Agricola, H.; Thissen, J. Participation rate of farmers in different multifunctional activities in the Netherlands. Outlook Agric. 2016, 45, 192-198. [CrossRef]

222. Wu, J.G. Linking landscape, land system and design approaches to achieve sustainability. J. Land Use Sci. 2019. [CrossRef]

223. McWilliam, W.; Fukuda, Y.; Moller, H.; Smith, D. Evaluation of a dairy agri-environmental programme for restoring woody green infrastructure. Int. J. Agric. Sustain. 2017, 15, 350-364. [CrossRef]

224. Bradley, B. Integrated Crop. In Management Systems in the EU: Amended Final Report for European Commission, DG Environment; Agra CEAS Consulting Ltd.: Ashford, UK, 2002. 
225. Mouchet, M.A.; Rega, C.; Lasseur, R.; Georges, D.; Paracchini, M.-L.; Renaud, J.; Stürck, J.; Schulp, C.J.; Verburg, P.H.; Verkerk, P.J. Ecosystem service supply by European landscapes under alternative land-use and environmental policies. Int. J. Biodivers. Sci. Ecosyst. Serv. Manag. 2017, 13, 342-354. [CrossRef]

226. Asquith, N.M.; Vargas, M.T.; Wunder, S. Selling two environmental services: In-kind payments for bird habitat and watershed protection in Los Negros, Bolivia. Ecol. Econ. 2008, 65, 675-684. [CrossRef]

(C) 2020 by the authors. Licensee MDPI, Basel, Switzerland. This article is an open access article distributed under the terms and conditions of the Creative Commons Attribution (CC BY) license (http://creativecommons.org/licenses/by/4.0/). 